\title{
Proteomic Responses of the Cyanobacterium Nostoc Muscorum under Salt and Osmotic Stresses
}

\author{
D. Gupta ${ }^{1}$, K. Bhardwaj ${ }^{2}$, R. Gothalwal ${ }^{1}$, S. Bhargava ${ }^{2 *}$ \\ ${ }^{1}$ Department of Biotechnology and Bioinformatics Centre, Barkatullah University, Bhopal 462026 M.P. \\ ${ }^{2}$ Division of Microbiology, Department of Botany, Government Motilal Science College, Bhopal 462008 M.P. \\ Email: santoshbhargava@hotmail.com
}

\begin{abstract}
In this paper, we examined the effect of salt stress $(\mathrm{NaCl})$ and osmotic stress (sucrose) on proteomic level in the diazotrophic cyanobacterium Nostoc muscorum. The aim of this study is to compare proteins appeared in control vs. salt treated, control vs. sucrose treated and salt treated vs. sucrose treated cultures. In the salt treated cultures about 37 proteins were expressed differentially out of these only 5 proteins have shown fold regulation of 1.5 or more. About 141 proteins were found to express independently in control and about 554 proteins were express independently in salt treated culture. When we compared proteins in control and sucrose treated cells, it was reported that about 37 protein spots were express differentially, out of these only 7 proteins have fold regulation 1.5 or more. The independently expressed proteins appeared on gel are 141 and 186 respectively. Similarly, when we compared proteins appeared in salt and sucrose treated cells, it was reported that about 54 proteins were express differentially, out of these 10 proteins have fold regulation 1.5 or more. About 537 protein spots were independently present in salt treated cells and about 186 proteins were independently present in sucrose treated cells. In addition, the differentially expressed proteins and their identification with their functional group have also been discussed.
\end{abstract}

Key words: Nostoc muscorum, osmotic stress, proteomic, salt stress

\section{Introduction}

Cyanobacteria are Gram negative eubacteria, their evolutionary history dated back to 2.7 billion years ago [1]. The origin of cyanobacteria and the evolution of oxygenic photosynthesis have been considered as the most important event in the evolution of aerobic atmosphere. Cyanobacteria are known to be found in almost all the ecological niches with diverse environmental conditions. The native cyanobacterial species present in such habitats confronted with cation toxicity and water loss. The microorganisms, including cyanobacteria that grow and multiply in such stressful habitats have ability to change their morphological and physiological parameters to cope up with such stressful conditions [2]. The ionic component of the stress factor is usually overcome by the efflux mechanism driven by $\mathrm{Na}^{+} / \mathrm{H}^{+}$ antiporter activity or by the Mrp system [3,4,2]. On the other hand the osmotic component of the stress factor is overcome by the synthesis/accumulation of low molecular weight organic compounds collectively known as compatible solutes [5,6].

The nature and the biosynthesis of compatible solutes depend upon the habitat in which cyanobacteria grow. The fresh water cyanobacterial strains are known to synthesized sucrose, trehalose and proline as an osmotic balancer $[7,2,8]$. Glucosyl-glycerol is a major compatible solute synthesized by moderately halotolerant strains $[9,10]$. On the other hand hyper saline strains produce glycine-betaine or glutamate-betaine as compatible solutes [11,12].

The modern molecular biology techniques such as genomics and proteomics have provided valuable databases for the better understanding of many physiological and biochemical processes including cyanobacterial adaptation to salt and osmotic stresses. It is known that during such stresses cellular proteins either denatured or inactivated followed by altering other metabolic activities. During such stresses molecular chaperones play a vital role in maintaining cellular homeostasis $[13,14,15,16]$. The initial signal of environmental changes perceived by cell surface and ultimately transferred this signal to the cells. In the cyanobacterium Anabaena sp PCC 7120 it has been reported that about 18 cell surface associated proteins were over-expressed under stress conditions. These over-expressed proteins have 
involved in nucleic acid binding, protein synthesis, proteolytic activity, electron transfer and other proteins [17].

Salinity and osmotic stresses triggered distinct protein synthesis in the Anabaena species [18]. In this strain synthesis of several proteins was repressed by salinity stress. Similarly, some proteins were induced only under salinity stress. However, there are certain proteins which were induced by both salinity and osmotic stresses. In addition, salinity and osmotic stress have been known to induce some independently expressed proteins. In cyanobacteria, gene expression under salt and osmotic stresses, has been studied by Kanesaki, et al. [19]. Their findings indicate that about 28 genes were expressed only under salt stress condition, while those of 11 genes were expressed only in response to osmotic stress. In addition, 34 genes are expressed both under salinity and osmotic stresses. The products of some of these genes are hypothetical proteins whose functions have not been characterized so far.

In this study protein profile of the cyanobacterium Nostoc muscorum under salinity $(\mathrm{NaCl})$ and osmotic (sucrose) stress was compared in terms of commonly and differentially expressed proteins (control vs. treated and salt vs. sucrose).

\section{$2 \quad$ Materials and Methods}

\subsection{Organism and Growth Conditions}

The cyanobacterium is Nostoc muscorum, used in the present study is fresh water, filamentous and diazotrophic cyanobacteria that is capable of oxygenic photosynthesis. This species was grown in modified Chu No. 10 medium [20] for routine as well as for experimental purposes. The cultures were routinely grown in $250 \mathrm{ml}$ Erlenmeyer's flask containing $100 \mathrm{ml}$ of liquid medium and incubated in a culture room set at a temperature of $24 \pm 1^{\circ} \mathrm{C}$ and illuminated for $16 \mathrm{hrs}$ per day with cool daylight fluorescent tubes (intensity approximately $10-50 \mathrm{~W} / \mathrm{m}^{2}$ ). The culture medium was maintained at $\mathrm{pH}$ 7.5 with the help of $10 \mathrm{mM}$ HEPES-NaOH.

The survival studies revealed that $\mathrm{NaCl}$, at the concentration of $100 \mathrm{mM}$ was found lethal to the cyanobacterium N. muscorum. The osmotic stress was generated by the sucrose. Sucrose at the concentration of $250 \mathrm{mM}$ was found lethal to the $N$. muscorum. The diazotrophically grown cultures were exposed to the lethal doses of $\mathrm{NaCl}$ and sucrose for $12 \mathrm{hrs}$ and then inoculated into fresh diazotrophic growth medium for further use.

\subsection{Total Protein Extraction}

Exponentially grown cultures of the cyanobacterium were harvested by centrifugation (Remi C-24BL, India) and the cell suspension was washed thrice with culture medium. The cell pellets thus obtained were weighted and then mixed in five times their volume of extraction buffer (B1). Then the mixture was grind with mortar pestle in liquid nitrogen three times followed by Sonication (Sonic Vibra-cell, USA) 10 times (70\% intensity) for 20s each with an ice bath, with 40s cooling breaks. The homogenate was centrifuged for $45 \mathrm{~min}$ at $16000 \mathrm{~g}$ at $4^{\circ} \mathrm{C}$ [21]. The supernatant thus obtained designated as total soluble protein fractions. The precipitation of protein was done with the help of trichloroacetic acid (TCA). Protein quantification of the extracted protein was carried out with the help of standard curve (BSA).

\subsection{TCA Precipitation}

The TCA precipitated protein was free of various non-protein contaminants which can interfere with isoelectric focusing and electrophoresis, such as lipids and salts. Extracted impure protein was precipitated by a mixture of TCA and chilled acetone in the ratio of 1:1:8 (impure protein: TCA: Acetone) for more than 2 hours. Precipitated proteins were washed thrice, first wash with $70 \%$ chilled acetone containing $0.07 \%$ DTT and the rest of the two wash with $70 \%$ chilled acetone only [22]. 


\subsection{2-Dimensional Gel Electrophoresis (2DE)}

Two-dimensional polyacrylamide gel electrophoresis (2-D PAGE) (O'Farrell, 1975) is the method in which protein molecules are separated according to the charge (pI) by isoelectric focusing (IEF) in the first dimension and according to the size $(\mathrm{Mw})$ by SDS-PAGE in the second dimension. 2-DE has a unique capacity for the resolution of complex mixtures of proteins, permitting the simultaneous analysis of hundreds or even thousands of gene products.

The protein sample was solubilized in appropriate amount of rehydration buffer and rehydration of immobilized pH gradient dry strip gel, IEF, equilibrium of IPG strip for proper protein transfer and SDS-PAGE were performed as described previously by Gupta et al [23].

\subsection{Image Scanning and Image Acquisition}

Gel imaging was performed on an Image Scanner III (GE Healthcare Bio-Sciences Ltd, India) and the image was saved in .tif (dot tif) and .mel (dot mel) format. Image acquisition was done using Image Master 2D Platinum 7 (IMP7, GE Healthcare, Freiburg, Germany) software. Protein spots of the gel were further analyzed using images of 2DE followed by calculation by Image Master 2D Platinum version 7.0 (GE Healthcare) software. The theoretical pI and molecular weight of overall functional annotation of the data were received by Expasy (http://web.expasy.org/compute_pi/Mw).

On the basis of their function these proteins are grouped into nine classes viz. (i) hypothetical, (ii) cellular processes, (iii) amino acid biosynthesis, (iv) photosynthesis and respiration, (v) energy metabolism, (vi) biosynthesis of cofactors, prosthetic groups, and carriers, (vii) cell envelope, (viii) central intermediary metabolism, (ix) fatty acid, phospholipid and sterol metabolism (http://www.kazusa.or.jp/cyano/ Anabaena/index.html).

\section{$3 \quad$ Results and Discussion}

In this study proteomics of the cyanobacterium $N$. muscorum under salt and osmotic stresses have been analyzed. This analysis has paved the way to compare protein spots in terms of differentially expressed and independently expresses proteins. The protein spots and multiple protein spots that showed fold regulation 1.5 or more [24] were further categorized into various functional groups and their role in salt and osmotic stresses. The 2-DE images showed that most of the protein spots were detected in a $\mathrm{pH}$ range of 4-7 and their molecular mass lies in the range of $10-90 \mathrm{kDa}$.

\subsection{D Analysis of Proteins under Salt Stress}

The protein spots appearing in control as well as in its salt treated cells were compared, as shown in table-1 about 37 proteins were expressed differentially. Out of these only 5 protein spots have showed fold regulation of 1.5 or more. The differentially expressed proteins and their identifications on the basis of their functional group are summarized in table-2. The spots which are marked by sign + in the Fig. 1 $(\mathrm{G} \& \mathrm{H})$ are independently present in control (141 spots) and salt treated cells (554 spots). Out of these protein spots, some proteins were found to occur in two or more spots. These multiple spots have similar molecular masses, but different $\mathrm{pI}$ values. The variation in $\mathrm{pI}$ value reflects post translation modification in the concerned protein molecule. On the contrary, some multiple spots of the same protein showed difference in their molecular masses. The various functional categories of differentially expressed proteins are discussed below: 

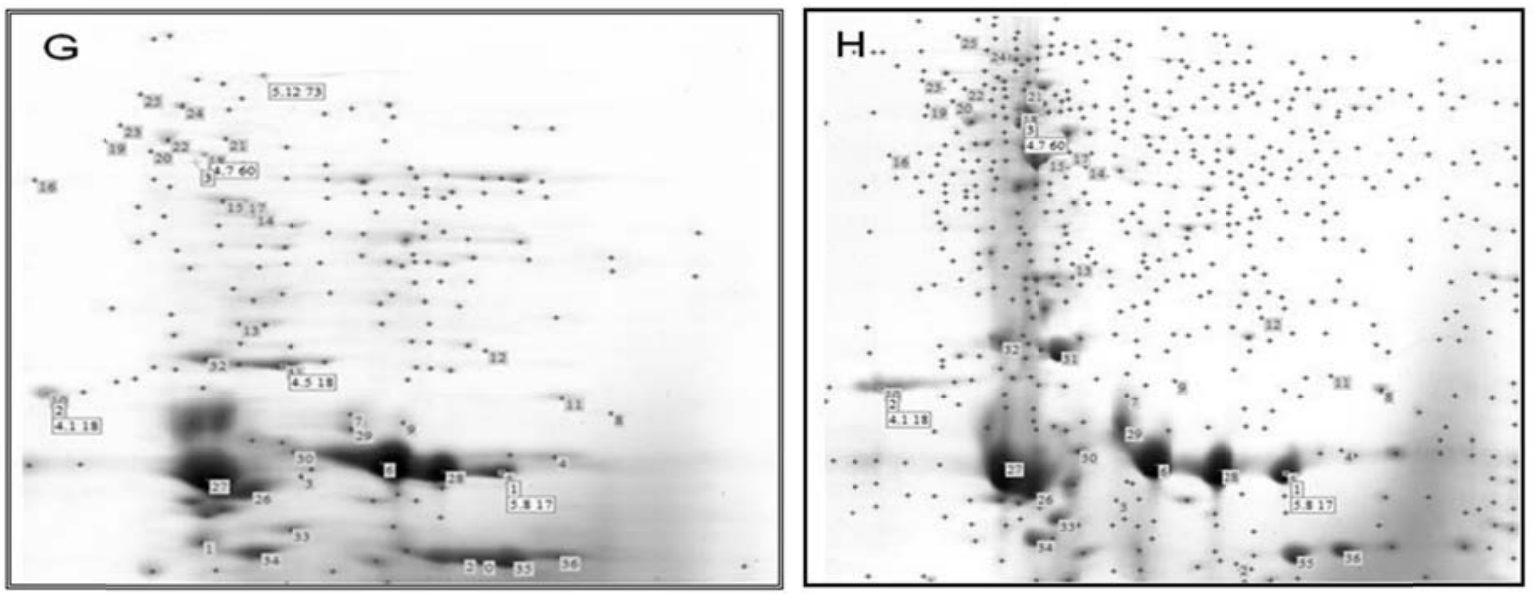

Figure 1. G and $\mathbf{H}$ Protein composition of total soluble protein fractionation from $N$. muscorum cells were grown under control $(\mathrm{G}$,$) and salt condition (\mathrm{H}, 100 \mathrm{mM} \mathrm{NaCl})$; proteins were separated using, 2D-PAGE and stained with Coomassie brilliant blue (CBB). Spot No: 0-36 (37 spots) are present in both control (G) and also in salt (H), but are differentially expressed. Other spots: marking by $(+)$ are independently present in both.

\subsubsection{Biosynthesis of Cofactors, Prosthetic Groups, and Carriers}

Protein spot differentially expressed under this category was identified as 2-sucicinyl-5-enolpyruvyl-6hydroxy-3-cyclohexene-1-carboxylate synthase. This protein synthesized from 2-oxoglutrate and isochorismate in menaquinone biosynthesis $(m e n D)$. In prokaryotes, menaquinone is an important component of the electron transport system [25]. As reported previously various genes involved in menaquinone biosynthesis help in maintaining balance between the two photosystems to work in a coordinate manner [26,27].

\subsubsection{Cellular Processes}

In cyanobacteria the function of the two component regulatory systems which consists of sensors and transducers of various abiotic stresses depends upon the degree of super-coiling of the genomic DNA [28]. This mechanism regulates transcription of stress induced genes for successful acclimatization of cells under stress conditions. In this study, differentially expressed protein Hsp70 identified as chaperones protein DnaK3. The role of molecular chaperones in maintaining protein conformational homeostasis is the key factor to the stress adaptability of cyanobacteria [29]. DNaK3 is a thylakoid membrane located protein and may be involved in protein folding in thylakoid [30]. Similar protein has also been induced under salt and osmotic stress in the unicellular cyanobacterium Synechocystis sp PCC 6803 [31], and also in the filamentous cyanobacteria Anabaena sp PCC 7120 [32].

\subsubsection{Energy Metabolism}

In Synechocystis sp PCC 6803, the operation of photorespiration has been reported by Bauwe, et al, [33]. They reported the existence of glycolate metabolism and glycerate pathway in the examined cyanobacterium. Like unicellular cyanobacteria glycolate metabolism has also been reported in filamentous cyanobacteria i. e. Anabaena sp. under salt stress [34,35]. In the present analysis similar to the S-layer RTX-protein found to express differentially, this involved in glycolate pathway. The study of Srivastava et al. [35] has pointed out the role of a glycolate oxydase gene (all0170) in salt acclimation. Therefore, it is suggested that genes involved in the glycolate pathway up regulated during salt shock. In addition, some cell surface-associated proteins (S-layer) also assembled into macromolecule structures that play an important role in cell physiology [17].

\subsubsection{Unknown and Hypothetical}

Phycobillisomes are the major light harvesting complexes of cyanobacteria. They are associated with photosytem II and constitute up to 50\% of the total cellular proteins. Phycobillisomes are multiprotein assemblies and under diazotrophic growth, various genes involved in phycobillisome proteins are over expressed [36]. In consistence with the above findings, it was found that orf viz. alr0021 which is annotated as allophycocyanin alpha subunit was over expressed under salt stress. 
Another hypothetical protein identified as endodeoxyribonuclease $\mathrm{RuvC}$ over expressed under salt stress. This protein involved in DNA replication, DNA repair and endonuclease binding protein. Similar proteins were also reported to over express under heat shock stress in the cyanobacterium Synechocystis sp PCC 6803 [37]. In the filamentous cyanobacterium Anabaena sp. strain PCC7120, cell surfaceassociated proteins were also reported to involve in nucleic acid binding under stress conditions [17].

In addition to the above mentioned differentially expressed protein, there are a large number of proteins that were identified in the control as well as in salt treated cells, which were expressed independently. This observation suggested that salt stress caused over expression of certain genes and simultaneous repression of certain genes. This metabolic plasticity in terms of up regulation and down regulation of genes helps in surviving cells under the given stresses.

\subsection{D Analysis of Proteins under Sucrose Stress}

The protein spots in control and its sucrose treated cells were compared, and it was reported that about 37 proteins were expressed differentially as shown in table-3. Out of these only 7 protein spots have fold regulation 1.5 or more. The differentially expressed proteins and their identifications with their functional group are summarized in table- 4 . The spots which are marked by sign + are independently present in control (141 spots) and sucrose treated cells (186 spots) Fig.2 (I and J). The various categories of differentially expressed proteins are given below:
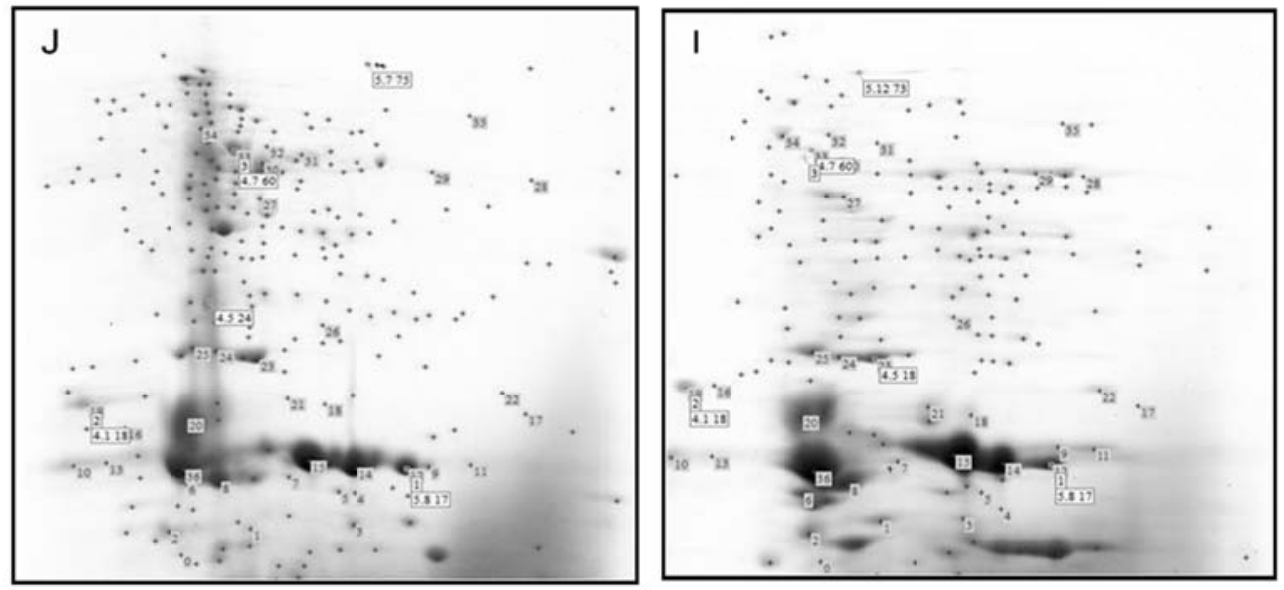

Figure 2. I and J. Protein composition of total soluble protein fractionation from N. muscorum. Cells were grown under control (I,) and sucrose condition (J, 250mM sucrose); proteins were separated using 2D-PAGE and stained with Coomassie brilliant blue (CBB). Spot No: 0-36 (37 spots) are present in both control (I) and also in sucrose $(\mathrm{J})$, but are differentially expressed. Other spots: marking by $(+)$ are independently present in both.

\subsubsection{Cell Envelope}

In this group penicillin binding protein, which is involved in the synthesis of the peptidoglycan layer of the cell wall has been differentially expressed. Since the sucrose stress was given to diazotropically grown culture, therefore it is suggested that over expression of penicillin binding proteins is essential for the formation of the peptidoglycan layer. Similar role of penicillin binding protein has also been elucidated by Lazaro et al. [38] in the cyanobacterium Anabaena sp PCC 7120 under normal condition. The role of penicillin binding protein in heterocyst development and in the remodeling of peptidoglycan layer has also been reported in the cyanobacterium Anabaena sp PCC 7120 [39].

\subsubsection{Energy Metabolism}

Phototrophic organisms like cyanobacteria use carbohydrates as carbon source to buildup cellular material and provide reductants. The carbohydrate molecules synthesized during the photosynthesis are broken down through various respiratory pathways. In our analysis the enzyme 2, 3-bisphosphoglycerate has been found to express differentially. This enzyme catalyses the inter conversion of 2phosphoglycerate and 3- phosphoglycerate. It is a major regulator of glycolysis and regulates the flux of 
carbon through the Kelvin Benson Cycle and its export in to glycolysis [40]. Another protein in this group identified as phosphoenolpyruvate synthase (all3147) catalyzes the phosphorylation of pyruvate and phosphoenolpyruvate in the presence of ATP molecules. The role of phosphoenolpyruvate synthase as an alternative phosphoenolpyruvate degradation has been reported in Synechococcus sp PCC 7002 under light stress condition [41]. The expression of genes involved in energy metabolism under stress condition is the key factors involved in cyanobacterial adaptation to stress factors [42].

\subsubsection{Central Intermediary Metabolism}

The expression level of alr0692 was higher in the nitrogen depletion condition. This ORF identified as a NifU like protein, it harbors NifU like domain partially over lapping a thioredoxine like domain. Thioredoxine catalyzing the reduction of intermolecular disulphide bonds by this means it plays a major role in the formation of Fe-S clusters [43]. The differentially expression of this protein may be related to the assembly of a functional uptake hydrogenase. The gene involved in assembly of hydrogenase should be regulated differentially depending on strains, environment and type of hydrogenase [44]. The differential expressions of this protein in the present investigation are inconsistent with the above hypothesis.

Another enzyme of this group i,e. inorganic pyrophosphatase catalyses the conversions of diphosphate to phosphate, induced differentially. Its role in metabolism is thought to be the removal of inorganic pyrophosphate, which is a byproduct of many anabolic reactions. It is also believed that pyrophosphate also plays an important role in the bioenergetics under various biotic and abiotic stresses [45,46,47].

\subsubsection{Unknown \& Hypothetical}

Phototrophs like cyanobacteria might use gas vesicle to expose them into appropriate light intensity. These gas vesicles are basically protein bodies and in prokaryotes they evolutionary most conserved bodies. In the cyanobacterium Anabaena sp. five additional proteins were identified (Gbp-F, Gbp-G, Gbp-j, Gbp-l and Gbp-M). These proteins are involved in the initiations of vesicle formation. In cyanobacteria buoyancy is regulated either by the formation of gas vesicle or synthesis/breakdown of carbohydrate molecules [48]. Our findings regarding the over expression of various proteins are inconsistent with the above finding.

The ATP binding protein i. e. alr2300 has identified as conserved hypothetical proteins in the present study. The over expression of this protein (HetY) suppresses the heterocyst formation [49]. In the sucrose treated cells heterocyst differentiations delayed as compared to the control. This delay in heterocyst differentiation correlated with the expression of alr2300 gene.

In addition, to the above mentioned differentially expressed protein, there are a number of proteins that were identified in the control as well as sucrose treated cells, which were expressed independently. This observation suggested that sucrose stress caused over expression of certain genes and simultaneous repression of certain genes. This up regulation and down regulation of certain genes helps in surviving cells under the given stresses.

\section{2D Analysis of Protein under Salt and Sucrose Stress}

In the next series of analysis we compared salt treated and osmotic treated samples in terms of commonly expressed proteins (Table 5). The protein spots with fold regulation 1.5 or more and their identification with functional group are given in table 6 . The spots which are marked by sign + are independently present in salt (537 spots) and sucrose treated cells (186 spots), Fig. 3 (K and L). 

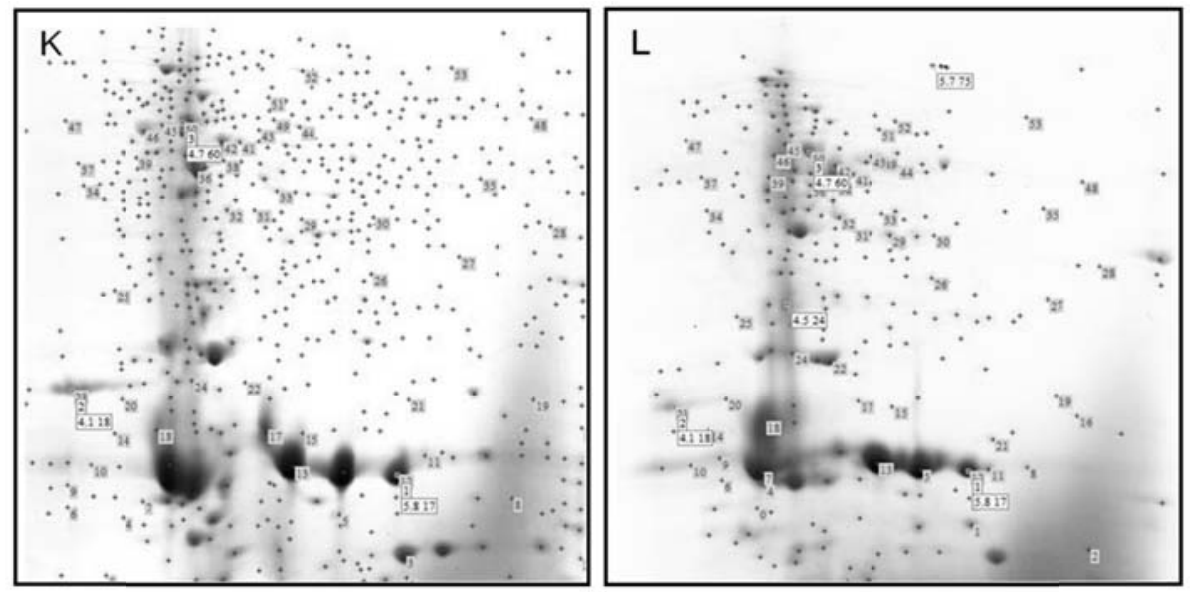

Figure 3. K and L Protein composition of total soluble protein fractionation from N.muscorum. Cells were grown under salt condition $(\mathrm{K}, 100 \mathrm{mM} \mathrm{NaCl})$ and sucrose condition (L, 250mM sucrose); proteins were separated using 2D-PAGE and stained with Coomassie brilliant blue (CBB). Spot No: 0-53 (54 spots) are present in both salt $(\mathrm{K})$ and also in sucrose $(\mathrm{L})$, but are differentially expressed. Other spots: marking by $(+)$ are independently present in both.

\subsection{Amino Acid Biosynthesis}

In this category the only protein belongs to glutamate family i. e. arginine biosynthesis bifunctional protein ArgJ2 was found to express differentially. This protein involved in the cyclic version of arginine biosynthesis; the synthesis of N-acetylglutamate from glutamate and acetyl Co-A as the acetyl donor, and of ornithine by transacetylation between $\mathrm{N}(2)$-acetyl ornithine and glutamate [50,51].

\subsection{Biosynthesis of Cofactors, Prosthetic Groups, and Carriers}

Biosynthesis of the PSI cofactor i. e. phylloquinone occurs in almost all photosynthetic organisms, including cyanobacteria. This cofactor is analogous to that of menaquinone a mobile electron carrier in many bacterial bioenergetic systems [25]. Any up shift or down shift in the environmental factor poses an additional energy burden in terms of cellular metabolism. Since the experimental organism exposed to salinity and osmotic stresses, therefore the over expression of $\mathrm{MenD}$ is justified. Similar role of men $D$ operon in bacteria and in algae has also been reported $[25,52]$.

\subsection{Cellular Processes}

The phenomenon of programmed cell death or apoptosis is very rare in prokaryotes. In cyanobacteria programmed cell death is associated with membrane integrity, leakage of proteases and DNA degradation. Studies on heamolysin produced by glucose tolerant strain of Synechocystis sp PCC 6803 suggested that heamolysin produced by this strain has no toxic activity [53]. In contrast, haemolysin obtained from wild type cells of Synechocystis sp PCC 6803 showed haemollytic activity against erythrocytes [54]. The haemolysin like protein was found to express differently in our study, however; we are unable to interpret the exact role of haemolysin production in this study.

The cyanobacterial heat shock response has already been studied both at the transcription level and expression level of specific genes and proteins [55]. The Hsp60/Hsp10 family also referred to as the GroE chaperone machinery in this study the experimental organism exhibit differential expression of two heat shock proteins encoded by Gro-EL1 and Gro-EL2 [56]. In addition, a 60kDa chaperonin 2 (Gro-EL2) was also found to express differentially in this study. It was also observed an increased in the expression level of protease (all2263). In photosynthetic organisms it has been reported that abiotic stresses not only over expressed proteins/enzyme involved in the main metabolic pathways, but also in the synthesis of Gro-EL1 and Gro-EL2 chaperonin and N-ATP dependent proteases [57,58]. The constitutive expression of these Hsps in the examined cyanobacterium suggests their role in stress tolerance. 


\subsection{Photosynthesis and Respiration}

Cyanobacterial nitrogen fixation is an energy requiring process; it requires ATP and a reductant for efficient nitrogen fixation. The over expressions of NADH dehydrogenase under stress conditions produce more ATP and a reductant to support nitrogen fixation and other metabolic activities. The protein involved in energy metabolism (photosynthesis and respiration) e.g. NADPH quinone oxidoreductase and NADH-plastoquinone oxidoreductase was highly abundant in the present analysis. This suggested that more ATP and a reductant is available to the organism for nitrogen fixation. Similar finding has also been reported by many workers $[35,36]$.

\subsection{Unknown \& Hypothetical}

Arginyl-tRNA synthetase (ArgRS) is known to responsible for aminoacylating its cognate tRNA(s) with a unique amino acid in a two-step catalytic reaction. In the first step amino acid t-RNA ligases binds to the amino acid, ATP to activate the amino acid through the formation of $\mathrm{N}$-aminoacyl-Adenylate. The second step involved the transfer of aminoacyl of the t-RNA.

Phycobillisomes are the major light harvesting complexes of cyanobacteria under nitrogen fixing condition and under salt stress conditions; major component of the phycobilisomes is strongly expressed $[36,59]$. The above findings are in agreement with our interpretations.

Phosphoglycerate kinase (PGK) is an enzyme that catalyzes the reversible transfer of a phosphate group from 1,3-bisphosphoglycerate (1,3-BPG) to ADP producing 3-phosphoglycerate (3-PG) and ATP during carbohydrate metabolism. The differentially expression of this protein suggested that the interaction of metabolic protein associated with the survival of the organism under stress condition. Similar role of carbohydrate metabolism in stress has also been reported in Anabaena sp. [60].

The enzyme 1,4-dihydroxy-2-naphthoyl-CoA hydrolase is known to be involved in the formation of a nephthaquonone ring of phylloquinone. In higher plants the cleavage of this enzyme leads to formation of phylloquinone; the cognate thioestrase of the same enzyme has been recently characterized in the cyanobacterium Synechocystis sp [61]. In photoautotrophic organisms, including certain species of cyanobacteria phylloquinone is a vital redox cofactor required for electron transfer in PSI and the formation of protein disulphide bond $[62,63,64]$. In consistence with the above findings, in cyanobacterium Synechocystis sp. PCC 6803, salt stress enhances the expression of genes of ribosomal proteins (rpl2, rpl3, rpl4 and rpl23), on the other hand hyperosmotic stress, enhances the expression of genes for the synthesis of lipids and lipoproteins ( $f a b G$ and $r l p A$ ) and for other functions. The over expression of these genes clearly indicates that Synechocystis sp. PCC 6803 recognizes salt stress and hyperosmotic stress as different signals. To the best of our knowledge this is the first report from the Nostoc muscorum investing proteomic responses under salt and osmotic stress.

\section{Conclusion}

The over expression of commonly induced proteins under salt and osmotic stress suggested that some factors might perceive and transducer such signals of the specific pathways that control the expression of a number of genes. Therefore; the role of various differently expressed proteins is to overcome given stress for the normal functioning of the cell. This metabolic adaptability of the cyanobacteria could be useful in the production of biofertilizer for stressful ecosystems and isolation of commercially important bioactive compounds.

Acknowledgements. Authors are thankful to Indian Institute of Science Education and Research (IISER), Bhopal, for providing 2DGE facility. DG and RG are also thankful to Bioinformatics Centre, Barkatullah University, Bhopal for providing necessary facilities under BTIS NET (DBT Govt. of India, New Delhi). 


\section{References}

1. R. Buick, "The antiquity of oxygenic photosynthesis: evidence from stromatolites in sulphate-deficient," Archaean lakes science, vol. 255 no. 5040 pp. 74-77, 1992.

2. M. Hagemann, "Molecular biology of cyanobacterial salt acclimation," FEMS microbiology review, vol. 35 no. 1 pp. 87-123, 2011.

3. K. Inaba, T. Kuroda, T. Shimamoto, T. Kayahara, M. Tsuda and T. Tsuchiya, "Lithium toxicity and $\mathrm{Na}+(\mathrm{Li}+) / \mathrm{H}+$ antiporter in Escherichia coli," Biological and pharmaceutical bulletin, vol. 17 no. 3 pp. 395-398, 1994.

4. R. Waditee, T. Hibino, T. Nakamura, A. Incharoensakdi and T. Takabe, "Overexpression of a Na+/H+ antiporter confers salt tolerance on a freshwater cyanobacterium, making it capable of growth in sea water," Proceedings of the national academy of sciences of the USA, vol. 99 no. 6 pp. 4109-4114, 2002.

5. E. A. Alia and I. A. Gahiza, "Accumulation of amino acids in Anabaena oryzae in response to sodium chloride salinity," Journal of applied science research, vol. 3 no. 3 pp. 263-266, 2007.

6. L. N. Csonka, "Physiological and genetic responses of bacteria to osmotic stress," Microbiology review, vol. 53 no.1 pp. 121-147, 1989.

7. M. Hagemann, A. Schoor and N. Erdmann, "NaCl acts as a direct modulator in the salt adaptive response: saltdependent activation of glucosylglycerol synthesis in vivo and in vitro," Journal of plant physiology, vol. 149 no. 6 pp. 746-752, 1996.

8. A. K. Singh, D. Chakarvarthy, T. P. K. Singh and H. N. Singh, "Evidence for a role of L-proline as a salinity protectant in the cyanobacterium Nostoc muscorum," Plant cell and environment, vol. 19 no. 4 pp. 490-494, 1996.

9. D. K. Hincha and M. Hagemann, "Stabilization of model membranes during drying by compatible solutes involved in the stress tolerance of plants and microorganisms," Biochemical journal, vol. 383 no. 2 pp. 277-283, 2004 .

10.K. Marin, M. Stirnberg, M. Eisenhut, R. Kramer and M. Hagemann, "Osmotic stress in Synechocystis sp. PCC 6803: low tolerance towards nonionic osmotic stress results from lacking activation of glucosyl-glycerol accumulation," Microbiology, vol. 152 no. 7 pp. 2023-2030, 2006.

11.S. Klahn, C. Steglich, W. R. Hess and M. Hagemann, "Glucosylglycerate: a secondary compatible solute common to marine cyanobacteria from nitrogen-poor environments," Environmental microbiology, vol. 12 no. 1 pp. 83-94, 2010 .

12.S. R. C. Warr, R. H. Reed and W. D. P. Stewart, "The compatibility of osmotica in cyanobacteria," Plant cell and environment, vol. 11 no. 2 pp. 137-142, 1988.

13.A. L. Horwich, W. A. Fenton, E. Chapman and G. W. Farr, "Two families of chaperonin: physiology and mechanism," Annual review of cell and developmental biology, vol. 23 no. pp. 115-145, 2007.

14.K. A. Krishna, G. V. Rao and K. R. Rao, "Chaperonin GroEL: structure and reaction cycle," Current protein and peptide science, vol. 8 no. 5 pp. 418-425, 2007.

15.S. Sharma, K. Chakraborty, B. K. Muller, N. Astola, Y. C. Tang, D. C. Lamb, M. Hayer-Hartl and F. U. Hartl, "Monitoring protein conformation along the pathway of chaperonin-assisted folding," Cell, vol. 133 no. 1 pp. $142-$ $153,2008$.

16.Y. C. Tang, H. C. Chang, K. Chakraborty, F. U. Hartl and M. Hayer-Hartl, "Essential role of the chaperonin folding compartment in vivo," EMBO journal, vol. 27 no. 10 pp. 1458-1468, 2008.

17.H. Yoshimura, M. Ikeuchi and M. Ohomori, "Cell surface-associated proteins in the filamentous cyanobacterium Anabaena sp. strain PCC 7120," Microbes and environments, vol. 27 no. 4 pp. 538-543, 2012.

18.T. A. Fernandes, V. Iyer and S. K. Apte, "Differential responses of nitrogen-fixing cyanobacteria to salinity and osmotic stresses." Applied and environmental microbiology, vol. 59 no. 3 pp. 899-904, 1993.

19.Y. Kanesaki, I. Suzuki, S. I. Allakhverdiev, K. Mikami and N. Murata, "Salt stress and hyperosmotic stress regulate the expression of different sets of genes in Synechocystis sp. PCC 6803," Biochemical and biophysical research communication, vol. 290 no. 1 pp. 339-348, 2002.

20.C. Gerloff, G. P. Fitzerald and F. Skoog, "The isolation, purification, and culture of blue-green algae," American journal of botany, vol. 37 no. 3 pp. 216-218, 1950.

21.Ran, F. Huang, M. Ekman, J. Klint and B. Bergman, "Proteomic analysis of the photoauto- and diazotrophically grown cyanobacteria Nostoc sp. PCC 73102," Microbiology, vol. 153 no. pp. 608-618, 2007. 
22.Méchin, C. Damerval and M. Zivy, "Total Protein Extraction with TCA-Acetone". In: Methods in Molecular Biology, Plant Proteomics: Methods and Protocols. vol. 335 no. pp. 335, 2007.

23.Gupta, R. Gothalwal and S. Bhargava, "Proteomic analysis of the cyanobacterium Synechococcus cedrorum IU 1191 under short term NaCl exposure," Current proteomics, vol. 12 no. 2 pp. 87-95, 2015.

24.F. Smith and M. S. Waterman, "Identification of common molecular subsequences," Journal of molecular biology, vol. 147, no. 1, pp. 195-197, 1981.

25.X. Y. Zhi, J. C. Yao, S. K. Tang and W. J. Li, "The futalosine pathway played an important role in menaquinone biosynthesis during early prokaryotic evolution," Genome biology and evolution, vol. 6 no. 1 pp. 149-160, 2014.

26.T. W. Johnson, S. Naithani, C. J. Stewart, B. Zybailov, J. A. Daniel, J. H. Golbeck and P. R. Chitnis, "The men $\mathrm{D}$ and menE homologs code for 2-succinyl-6-hydroxyl-2,4 cyclohexadiene-1-carboxylate synthase and Osuccinylbenzoic acid-CoA synthase in the phylloquinone biosynthetic pathway of Synechocystis sp. PCC 6803,". Biochimica et biophysica acta, vol. 1557 no. pp. 67-76, 2003.

27.J. Gross, W. K. Cho, L. Lezhneva, J. Falk, K. Krupinska, K. Shinozaki, M. Seki, R. G. Herrmann and J. Meurer, "A plant locus essential for phylloquinone (vitamin K1) biosynthesis originated from a fusion of four eubacterial genes," Journal of biological chemistry, vol. 281 no.25 pp. 17189-17196, 2006.

28.J. S. Prakash, M. Sinetova, A. Zorina, E. Kupriyanova, I. Suzuki, N. Murata and D. A. Los, "DNA supercoiling regulates the stress-inducible expression of genes in the cyanobacterium Synechocystis," Molecular bisystems, vol. 5 no. 12 pp. 1904-1912, 2009.

29.H. Rajaram, A. K. Chaurasia and S. K. Apte, "Cyanobacterial heat-shock response: role and regulation of molecular chaperones," Microbiology, vol. 160 no. 4 pp. 647-658, 2014.

30.H. Rupprecht, S. Gathmann, E. Fuhrmann and D. Schneider, "Three different DnaK proteins are functionally expressed in the cyanobacterium Synechocystis sp. PCC 6803," Microbiology, vol. 153 no. pp. 1828-1841, 2007.

31.D. A. Los, A. Zorina, M. Sinetova, S. Kryazhov, K. Mironov and V. V. Zinchenko, "Stress sensors and signal transducers in cyanobacteria," Sensors, vol. 10 no. 3 pp. 2386-2415, 2010.

32.P. K. Singh, S. Rai, S. Pandey, C. Agrawal, A. K. Shrivastava, S. Kumar and L. C. Rai, "Cadmium and UV-B induced changes in proteome and some biochemical attributes of Anabaena sp. PCC 7120," Phykos, vol. 42 no. 1 pp. 39-50, 2012.

33.H. Bauwe, M. Hagemann and A. R. Fernie, "Photorespiration: players, partners and origin," Trends in plant science, vol. 15 no. 6 pp. 330-336, 2010.

34.A. K. Srivastava, P. Bhargava and L. C. Rai, "Salinity and copper-induced oxidative damage and changes in antioxidative defense system of Anabaena doliolum," World journal of microbiology and biotechnology, vol. 21 no. 6 pp. 1291-1298, 2005.

35.A. K. Srivastava, R. Alexova, Y. J. Jeon, G. S. Kohli and B. A. Neilan, "Assessment of salinity-induced photorespiratory glycolate metabolism in Anabaena sp. PCC 7120," Microbiology, vol.157 no. 3 pp. 911-917, 2011.

36.R. Wünschiers, R. Axelsson, M. Vellguth and P. Lindblad, "Experimental and bioinformatic approaches for analyzing and visualizing cyanobacterial nitrogen and hydrogen metabolism," Electronic journal of biotechnology, vol. 10 no. 4 pp. 549-562, 2007.

37.J. J. Hall, "Proteomic analysis of the heat shock and acclimation responses of Cyanobacteria" A thesis submitted to the University of Durham for the degree of Doctor of Philosophy, 2005.

38.S. Lázaro, F. Fernández-Piñas, E. Fernández-Valiente, A. Blanco-Rivero and F. Leganés, "pbpB, a gene coding for a putative penicillin-binding protein, is required for aerobic nitrogen fixation in the cyanobacterium Anabaena sp. strain PCC 7120," Journal of bacteriology, vol. 183 no. 2 pp. 628-636, 2001.

39.S. Berendt, J. Lehner, Y. V. Zhang, T. M. Rasse, K. Forchhammer and I. Maldener, "Cell wall amidase AmiC1 is required for cellular communication and heterocyst development in the cyanobacterium Anabaena PCC 7120 but not for filament integrity," Journal of bacteriology, vol. 194 no. 19 pp. 5218-5227, 2012.

40.J. Jablonsky, M. Hagemann, D. Schwarz and O. Wolkenhauer, "Phosphoglycerate mutases function as reverse regulated isoenzymes in Synechococcus elongatus PCC 7942," PLoS One, vol. 8 no. 3 pp. e58281, 2013.

41.M. Ludwig and D. A. Bryant, "Synechococcus sp. strain PCC 7002 transcriptome: acclimation to temperature, salinity, oxidative stress, and mixotrophic growth conditions," Frontiers in microbiology, vol. 3 no. pp. article $354,2012$. 
42.A. M. Ruffing, "RNA-Seq analysis and targeted mutagenesis for improved free fatty acid production in an engineered cyanobacterium," Biotechnology and biofuels, vol. 6 no. 1 pp. 113, 2013.

43.D. Johnson, D. R. Dean, A. D. Smith and M. K. Johnson, "Structure, Function and Formation of Biological Iron-Sulfur Clusters," Annual review of biochemistry, vol. 74 no. pp. 247-281, 2005.

44.A. Agervald, K, Stensjö, M. Holmqvist and P. Lindblad, "Transcription of the extended hyp-operon in Nostoc sp. strain PCC 7120," BMC Microbiology, vol. 8 no. pp. 69, 2008.

45.M. R. Gómez-García, M. Losada and A. Serrano, "Comparative biochemical and functional studies of family I soluble inorganic pyrophosphatases from photosynthetic bacteria," FEBS journal, vol. 274 no. 15 pp. 3948-3959, 2007.

46.J. R. Pérez-Castiñeira, R. Gómez-García, R. L. López-Marqués, M. Losada and A. Serrano, "Enzymatic systems of inorganic pyrophosphate bioenergetics in photosynthetic and heterotrophic protists: remnants or metabolic cornerstones? International microbiology, vol. 4 no. 3 pp. 135-142, 2001.

47.F. Serrano, J. M. Gonzáles-Donoso, P. Palmqvist, A. Guerra-Merchán, D. Linares and J. A. Pérez-Claros, "Estimating Pliocene sea-surface temperatures in the Mediterranean: An approach based on the modern analogs technique," Palaeogeography palaeoclimatology palaeoecology, vol. 243 no. 1-2 pp. 174-188, 2007.

48.K. F. Jarrell and M. J. McBride, "The surprisingly diverse ways that prokaryotes move," Nature reviews microbiology, vol. 6 no. 6 pp.466-476, 2008.

49.J. H. Yoon, K. H. Kang and Y. H. Park, "Psychrobacter jeotgalisp. nov., isolated from jeotgal, a traditional Korean fermented seafood," International journal of systematic and evolutionary microbiology, vol. 53 no. pp. 449-454, 2003.

50.F. Marc, P. Weigel, C. Legrain, Y. Almeras, M. Santrot and V. Sakanyanet, "Characterization and kinetic mechanism of mono- and bifunctional ornithine acetyltransferases from thermophilic microorganisms," European journal of biochemistry, vol. 267 no. 16 pp. 5217-5226, 2000.

51.F. Marc, P. Weigel, C. Legrain, N. Glansdorff and V. Sakanyan, "An invariant threonine is involved in selfcatalyzed cleavage of the precursor protein for ornithine acetyltransferase," Journal of biological chemistry, vol. 276 no. 27 pp. 25404-25410, 2001.

52.J. Gross, J. Meurer and D. Bhattacharya, "Evidence of a chimeric genome in the cyanobacterial ancestor of plastids," BMC Evolutionary biology, vol. 8 no. pp. 117, 2008.

53.T. Sakiyama, H. Ueno, H. Homma, O. Numata and T. Kuwabara, "Purification and characterization of a hemolysin-like protein, Sll1951, a nontoxic member of the RTX protein family from the Cyanobacterium Synechocystis sp. strain PCC 6803," Journal of bacteriology, vol. 188 no. 10 pp. 3535-3542, 2006.

54.W. W. Shuai, Z. Yuanyuan, R. U. Shaoguo and L. Yunzhang, "Studies on hemolysis of hemolysin produced by Synechocystis sp. PCC 6803," Journal of ocean university of China, vol. 10 no. 4 pp. 362-368, 2011.

55.D. A. Los, I. Suzuki, V. V. Zinchenko and N. Murata, "Stress responses in Synechocystis: regulated genes and regulatory systems" In: The Cyanobacteria: Molecular Biology, Genomics and Evolution (Herrero, A. and Flores, E., Eds.), Caister Academic Press, Norfolk. pp. 117-157, 2008.

56.S. Sato, M. Ikeuchi and H. Nakamoto, "Expression and function of a groEL paralog in the thermophilic cyanobacterium Thermosynechococcus elongatus under heat and cold stress," FEBS letters, vol. 582 no. 23-24 pp. 3389-3395, 2008.

57.A. K. Clarke, "ATP-dependent Clp proteases in photosynthetic organisms a cut above the rest"! Annals of botany, vol. 83 no. 6 pp. 593-599, 1999.

58.O. Castielli, B. De la Cerda, J. A. Navarro, M. Hervás and M. A. De la Rosa, "Proteomic analyses of the response of cyanobacteria to different stress conditions," FEBS letters, vol. 583 no. 11 pp. 1753-1758, 2009.

59.S. I. Allakhverdiev and N. Murata, "Salt stress inhibits photosystems II and I in cyanobacteria," Photosynthesis research, vol. 98 no. 1-3 pp. 529-539, 2008.

60.S. Pandey, R. Rai and L. C. Rai, "Proteomics combines morphological, physiological and biochemical attributes to unravel the survival strategy of Anabaena sp. PCC7120 under arsenic stress," Journal of proteomics, vol. 75 no. 3 pp. 921-937, 2012.

61.J. R. Widhalm, A. L. Ducluzeau, N. E. Buller, C. G. Elowsky, L. J. Olsen and G. J. Basset, "Phylloquinone (vitamin $\mathrm{K}(1)$ biosynthesis in plants: two peroxisomal thioesterases of lactobacillales origin hydrolyze 1,4dihydroxy-2-naphthoyl-coa," The plant journal, vol. 71 no. 2 pp. 205-215, 2012. 
62.A. K. Singh, M. Bhattacharyya-Pakrasi and H. B. Pakrasi, "Identification of an atypical membrane protein involved in the formation of protein disulfide bonds in oxygenic photosynthetic organisms," The journal of biological chemistry, vol. 283 no. 23 pp. 15762-15770, 2008.

63.J. Fort, Y. Cherel, A. M. A. Harding, C. Egevang, H. Steen, G. Kuntz, W. P. Porter and D. Grémillet, "The feeding ecology of little auks raises questions about winter zooplankton stocks in North Atlantic surface waters," Biology letters, vol. 23 no. 6(5) pp. 682-684, 2010.

64.M. Karamoko, S. Cline, K. Redding and P. P. Ruiz Namel, "Lumen Thiol Oxidoreductase1, a Disulfide BondForming Catalyst, Is Required for the Assembly of Photosystem II in Arabidopsis," The plant cell, vol. 23 no. 12 pp. 4462-4475, 2011.

\section{Appendix}

Table 1. Spot details on commonly induced proteins under salt treated cells verses control cells of N. muscorum. $\mathrm{NC}=$ protein spots apparent on the gel of control cells of N. muscorum; NN=protein spots apparent on the gel of salt treated cells of N. muscorum

\begin{tabular}{|c|c|c|c|c|c|c|c|c|c|c|}
\hline $\begin{array}{c}\text { File } \\
\text { Name }\end{array}$ & $\begin{array}{c}\text { Spot } \\
\text { ID }\end{array}$ & $\begin{array}{c}\text { Match } \\
\text { ID }\end{array}$ & $\begin{array}{c}\text { Apparent } \\
\text { pI }\end{array}$ & $\begin{array}{c}\text { Apparent } \\
\text { MW } \\
(\mathrm{kDa}) \\
\end{array}$ & $\%$ Vol & \begin{tabular}{|c|} 
Fold \\
Regulation \\
$(\mathrm{T} / \mathrm{C})$
\end{tabular} & $\begin{array}{l}\text { Protein } \\
\text { Acc. No }\end{array}$ & Protein Identfication & $\begin{array}{l}\text { Theoretical } \\
\text { Mw (Da) }\end{array}$ & $\begin{array}{l}\text { Theoretical } \\
\text { pI }\end{array}$ \\
\hline $\mathrm{NN}$ & 8431 & 36 & 6.029 & 16 & 0.84788 & \multirow[t]{2}{*}{1.19} & \multirow[t]{2}{*}{ Q8YQ24 } & \multirow[t]{2}{*}{ Chorismate mutase } & \multirow[t]{2}{*}{15706.02} & \multirow[t]{2}{*}{6.91} \\
\hline $\mathrm{NC}$ & 3279 & 36 & 6.133 & 16 & 0.71543 & & & & & \\
\hline $\mathrm{NN}$ & 8432 & 35 & 5.836 & 16 & 1.54506 & \multirow[t]{2}{*}{0.72} & \multirow[t]{2}{*}{ Q8YP58 } & \multirow{2}{*}{$\begin{array}{l}\text { Mannose-6-phosphate } \\
\text { isomerase }\end{array}$} & \multirow[t]{2}{*}{15804.86} & \multirow[t]{2}{*}{6.65} \\
\hline $\mathrm{NC}$ & 3277 & 35 & 5.857 & 16 & 2.13274 & & & & & \\
\hline $\mathrm{NN}$ & 8424 & 34 & 4.763 & 16 & 0.81515 & \multirow[t]{2}{*}{0.56} & \multirow[t]{2}{*}{ P58703 } & \multirow{2}{*}{\begin{tabular}{|l|} 
Cyanate hydratase \\
(Cyanase) (EC 4.2.1.104) \\
(Cyanate hydrolase) \\
(Cyanate lyase) \\
\end{tabular}} & \multirow{2}{*}{16398.99} & \multirow[t]{2}{*}{4.97} \\
\hline $\mathrm{NC}$ & 3276 & 34 & 5.091 & 16 & 1.46755 & & & & & \\
\hline $\mathrm{NN}$ & 8408 & 33 & 4.856 & 16 & 0.66589 & \multirow[t]{2}{*}{0.58} & \multirow[t]{2}{*}{ Q8YUT1 } & \multirow[t]{2}{*}{ Gas vesicle protein GvpJ } & \multirow[t]{2}{*}{16597.58} & \multirow[t]{2}{*}{4.73} \\
\hline $\mathrm{NC}$ & 3273 & 33 & 4.549 & 16 & 1.15037 & & & & & \\
\hline $\mathrm{NN}$ & 8281 & 32 & 4.617 & 22 & 1.92456 & \multirow[t]{2}{*}{1.28} & \multirow[t]{2}{*}{ P80562 } & \multirow{2}{*}{\begin{tabular}{|l} 
Inorganic \\
pyrophosphatase (EC \\
3.6.1.1) (Pyrophosphate \\
phospho-hydrolase) \\
(PPase) \\
\end{tabular}} & \multirow[t]{2}{*}{18960.61} & \multirow[t]{2}{*}{4.69} \\
\hline $\mathrm{NC}$ & 3228 & 32 & 4.710 & 19 & 1.50248 & & & & & \\
\hline $\mathrm{NN}$ & 8289 & 31 & 4.867 & 21 & 1.83581 & \multirow[t]{2}{*}{0.90} & \multirow[t]{2}{*}{ O52749 } & \multirow{2}{*}{$\begin{array}{l}\text { UPF0079 ATP-binding } \\
\text { protein alr2300 }\end{array}$} & \multirow[t]{2}{*}{17938.69} & \multirow[t]{2}{*}{4.33} \\
\hline $\mathrm{NC}$ & 3230 & 31 & 4.500 & 18 & 2.03955 & & & & & \\
\hline $\mathrm{NN}$ & 8362 & 30 & 4.945 & 17 & 0.71796 & \multirow[t]{2}{*}{0.66} & \multirow[t]{2}{*}{ O52751 } & \multirow[b]{2}{*}{\begin{tabular}{|l} 
Crossover junction \\
endodeoxyribonuclease \\
RuvC (EC 3.1.22.4) \\
(Holliday junction \\
nuclease RuvC) \\
(Holliday junction \\
resolvase RuvC) \\
\end{tabular}} & \multirow[t]{2}{*}{17740.55} & 4.7 \\
\hline $\mathrm{NC}$ & 3253 & 30 & 4.565 & 17 & 1.08462 & & & & & \\
\hline $\mathrm{NN}$ & 8342 & 29 & 5.127 & 18 & 2.34606 & 2.45 & P80555 & Allophycocyanin subunit & 17214.47 & 4.92 \\
\hline $\mathrm{NC}$ & 3249 & 29 & 4.914 & 18 & 0.95666 & & & alpha 1 & & \\
\hline $\mathrm{NN}$ & 8359 & 28 & 5.529 & 17 & 5.84423 & 1.04 & P80557 & Allophycocyanin subunit & 17173.56 & 5.46 \\
\hline $\mathrm{NC}$ & 3256 & 28 & 5.451 & 17 & 5.63804 & & & beta & & \\
\hline $\mathrm{NN}$ & 8358 & 27 & 4.628 & 17 & 7.99235 & 0.59 & 052751 & Crossover junction & 17740.55 & 4.7 \\
\hline
\end{tabular}




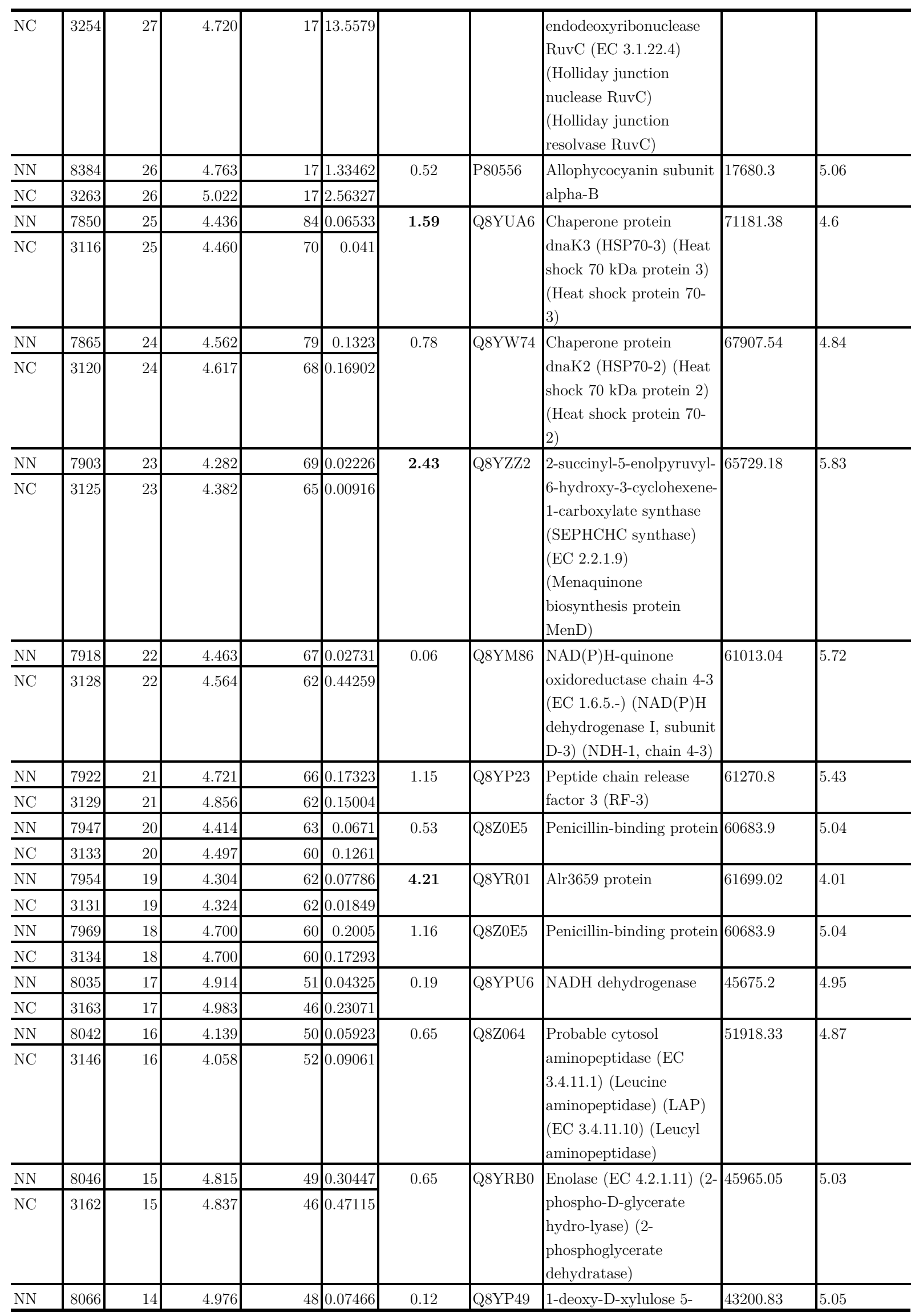




\begin{tabular}{|c|c|c|c|c|c|c|c|c|c|c|}
\hline $\mathrm{NC}$ & 3168 & 14 & 5.052 & 43 & 0.63857 & & & $\begin{array}{l}\text { phosphate } \\
\text { reductoisomerase (DXP } \\
\text { reductoisomerase) (EC } \\
\text { 1.1.1.267) (1- } \\
\text { deoxyxylulose-5- } \\
\text { phosphate } \\
\text { reductoisomerase) (2-C- } \\
\text { methyl-D-erythritol 4- } \\
\text { phosphate synthase) }\end{array}$ & & \\
\hline $\mathrm{NN}$ & 8205 & 13 & 4.924 & 31 & 0.03652 & \multirow[t]{2}{*}{0.10} & \multirow[t]{2}{*}{ Q8YNC5 } & \multirow[t]{2}{*}{ Peroxiredoxin } & \multirow[t]{2}{*}{22630.61} & \multirow[t]{2}{*}{4.87} \\
\hline $\mathrm{NC}$ & 3217 & 13 & 4.944 & 23 & 0.37055 & & & & & \\
\hline $\mathrm{NN}$ & 8267 & 12 & 5.701 & 25 & 0.03946 & \multirow[t]{2}{*}{0.94} & \multirow[t]{2}{*}{ Q8YLJ6 } & \multirow{2}{*}{$\begin{array}{l}\text { 50S ribosomal protein } \\
\text { L10 }\end{array}$} & \multirow[t]{2}{*}{19438.44} & \multirow[t]{2}{*}{5.71} \\
\hline $\mathrm{NC}$ & 3227 & 12 & 5.711 & 20 & 0.04217 & & & & & \\
\hline $\mathrm{NN}$ & 8309 & 11 & 5.982 & 19 & 0.01492 & \multirow[t]{2}{*}{0.03} & \multirow[t]{2}{*}{ Q8YNU3 } & \multirow[t]{2}{*}{ Alr4468 protein } & \multirow[t]{2}{*}{18080.98} & \multirow[t]{2}{*}{6.9} \\
\hline $\mathrm{NC}$ & 3243 & 11 & 6.158 & 18 & 0.48412 & & & & & \\
\hline $\mathrm{NN}$ & 8313 & 10 & 4.100 & 18 & 0.63671 & \multirow[t]{2}{*}{1.08} & \multirow[t]{2}{*}{ O52749 } & \multirow{2}{*}{$\begin{array}{l}\text { UPF0079 ATP-binding } \\
\text { protein alr2300 }\end{array}$} & \multirow[t]{2}{*}{17938.69} & \multirow[t]{2}{*}{4.33} \\
\hline $\mathrm{NC}$ & 3241 & 10 & 4.100 & 18 & 0.58712 & & & & & \\
\hline $\mathrm{NN}$ & 8315 & 9 & 5.341 & 19 & 0.04354 & \multirow[t]{2}{*}{0.07} & \multirow[t]{2}{*}{ Q8YYZ9 } & \multirow[t]{2}{*}{ Alr0692 protein } & \multirow[t]{2}{*}{17425.21} & \multirow[t]{2}{*}{5.37} \\
\hline $\mathrm{NC}$ & 3248 & 9 & 5.215 & 18 & 0.64891 & & & & & \\
\hline $\mathrm{NN}$ & 8325 & 8 & 6.191 & 18 & 0.28307 & \multirow[t]{2}{*}{1.16} & \multirow[t]{2}{*}{ Q8YWH5 } & \multirow[b]{2}{*}{$\begin{array}{l}\text { Molybdopterin synthase } \\
\text { catalytic subunit (EC } \\
2.8 .1 .12 \text { ) (MPT synthase } \\
\text { subunit 2) (Molybdenum } \\
\text { cofactor biosynthesis } \\
\text { protein E) } \\
\text { (Molybdopterin- } \\
\text { converting factor large } \\
\text { subunit) } \\
\text { (Molybdopterin- } \\
\text { converting factor subunit } \\
2 \text { ) } \\
\end{array}$} & \multirow{2}{*}{18097.81} & \multirow[t]{2}{*}{7} \\
\hline $\mathrm{NC}$ & 3247 & 8 & 6.442 & 18 & 0.24498 & & & & & \\
\hline $\mathrm{NN}$ & 8328 & 7 & 5.143 & 18 & 0.39368 & \multirow[t]{2}{*}{0.84} & \multirow[t]{2}{*}{ Q8YSE1 } & Phosphoenolpyruvate & 18033.87 & 4.85 \\
\hline $\mathrm{NC}$ & 3246 & 7 & 4.898 & 18 & 0.46624 & & & synthase & & \\
\hline $\mathrm{NN}$ & 8356 & 6 & 5.263 & 17 & 5.98757 & 0.49 & P80555 & Allophycocyanin subunit & 17214.47 & 4.92 \\
\hline $\mathrm{NC}$ & 3252 & 6 & 5.085 & 17 & 12.2443 & & & alpha 1 & & \\
\hline $\mathrm{NN}$ & 8360 & 5 & 5.800 & 17 & 3.38518 & 1.53 & O52751 & Crossover junction & 17740.55 & 4.7 \\
\hline $\mathrm{NC}$ & 3260 & 5 & 5.800 & 17 & 2.21081 & & & $\begin{array}{l}\text { endodeoxyribonuclease } \\
\text { RuvC (EC 3.1.22.4) } \\
\text { (Holliday junction } \\
\text { nuclease RuvC) } \\
\text { (Holliday junction } \\
\text { resolvase RuvC) } \\
\end{array}$ & & \\
\hline $\mathrm{NN}$ & 8365 & 4 & 6.029 & 17 & 0.11362 & 0.05 & Q93SX1 & Cytochrome b6-f & 17535.91 & 7.85 \\
\hline $\mathrm{NC}$ & 3257 & 4 & 6.117 & 17 & 2.14779 & & & $\begin{array}{l}\text { complex subunit } 4 \text { (17 } \\
\text { kDa polypeptide) }\end{array}$ & & \\
\hline $\mathrm{NN}$ & 8395 & 3 & 5.101 & 17 & 0.08298 & 1.24 & O52753 & Crossover junction & 17740.55 & 4.7 \\
\hline $\mathrm{NC}$ & 3262 & 3 & 4.614 & 17 & 0.06696 & & & $\begin{array}{l}\text { endodeoxyribonuclease } \\
\text { RuvC (EC 3.1.22.4) } \\
\text { (Holliday junction } \\
\text { nuclease RuvC) } \\
\text { (Holliday junction } \\
\text { resolvase RuvC) } \\
\end{array}$ & & \\
\hline $\mathrm{NN}$ & 8441 & 2 & 5.597 & 16 & 0.01524 & 0.02 & Q8Z0K8 & Alr0083 protein & 15901.34 & 5.64 \\
\hline
\end{tabular}




\begin{tabular}{l|l|l|r|r|r|r|l|l|l|l}
\hline $\mathrm{NC}$ & 3280 & 2 & 5.564 & 16 & 0.72198 & & & & & \\
\hline $\mathrm{NN}$ & 8450 & 1 & 4.287 & 16 & 0.06125 & 0.03 & Q8YUT1 & Gas vesicle protein GvpJ & 16597.58 & 4.73 \\
\hline $\mathrm{NC}$ & 3274 & 1 & 4.690 & 16 & 2.06072 & & & & & \\
\hline $\mathrm{NN}$ & 8452 & 0 & 5.737 & 16 & 0.14889 & 0.22 & Q8Z0K8 & Alr0083 protein & 15901.34 & 5.64 \\
\hline $\mathrm{NC}$ & 3281 & 0 & 5.678 & 16 & 0.67488 & & & & & \\
\hline
\end{tabular}

Table 2. Showing identical protein with differential expression ( $>1.5$ Fold Regulation) in the control and salt treated cells. The putative gene products are also given in the table.

\begin{tabular}{l|l|l|l|r|r}
\hline S.N. & Functional Group & Protein Identfication & Sub function & $\begin{array}{l}\text { Gene } \\
\text { Name }\end{array}$ & $\begin{array}{l}\text { Match } \\
\text { ID }\end{array}$ \\
\hline 1 & $\begin{array}{l}\text { Biosynthesis of cofactors, } \\
\text { prosthetic groups, and } \\
\text { carriers }\end{array}$ & $\begin{array}{l}\text { 2-succinyl-5-enolpyruvyl-6-hydroxy-3-cyclohexene-1- } \\
\text { carboxylate synthase (SEPHCHC synthase) (EC 2.2.1.9) } \\
\text { (Menaquinone biosynthesis protein MenD) }\end{array}$ & $\begin{array}{l}\text { Menaquinone and } \\
\text { ubiquinone }\end{array}$ & alr0312 & 23 \\
\hline 2 & Cellular processes & $\begin{array}{l}\text { Chaperone protein dnaK3 (HSP70-3) (Heat shock 70 kDa } \\
\text { protein 3) (Heat shock protein 70-3) }\end{array}$ & Chaperones & alr2446 & 25 \\
\hline 3 & Energy metabolism & similar to S-layer-RTX protein & $\begin{array}{l}\text { Glycolate } \\
\text { pathway }\end{array}$ & alr3659 & 19 \\
\hline & Unknown \& Hypothetical & Allophycocyanin subunit alpha 1 & & alr0021 & 29 \\
\cline { 2 - 5 } & $\begin{array}{l}\text { Crossover junction endodeoxyribonuclease RuvC (EC } \\
3.1 .22 .4) \text { (Holliday junction nuclease RuvC) (Holliday } \\
\text { junction resolvase RuvC) }\end{array}$ & all2297 & 5 & 5 \\
\hline
\end{tabular}

Table 3. Spot details on commonly induced proteins under sucrose treated cells verses control cells of N. muscorum. $\mathrm{NC}=$ protein spots apparent on the gel of control cells of $N$. muscorum; NS=protein spots apparent on the gel of sucrose treated cells of $N$. muscorum.

\begin{tabular}{|c|c|c|c|c|c|c|c|c|c|c|}
\hline $\begin{array}{l}\text { File } \\
\text { Name }\end{array}$ & $\begin{array}{l}\text { Spot } \\
\text { ID }\end{array} \mid$ & $\begin{array}{l}\text { Match } \\
\text { ID }\end{array}$ & $\begin{array}{l}\text { Apparent } \\
\text { pI }\end{array}$ & $\begin{array}{l}\text { Apparent } \\
\mathrm{MW} \\
(\mathrm{kDa})\end{array}$ & $\% \mathrm{Vol}$ & \begin{tabular}{|l|} 
Fold \\
Regulation \\
Value \\
$(\mathrm{t} / \mathrm{c})$ \\
\end{tabular} & $\begin{array}{l}\text { Protein } \\
\text { Acc. No }\end{array}$ & Protein Identfication & $\begin{array}{l}\text { Theoretical } \\
\text { Mw (Da) }\end{array}$ & $\begin{array}{l}\text { Theoretical } \\
\text { pI }\end{array}$ \\
\hline NS & 3770 & 36 & 4.414 & 17 & 9.6733 & \multirow{2}{*}{0.71} & \multirow[t]{2}{*}{ O52751 } & \multirow[b]{2}{*}{$\begin{array}{l}\text { Crossover junction } \\
\text { endodeoxyribonuclease } \\
\text { RuvC (EC } 3.1 .22 .4 \text { ) } \\
\text { (Holliday junction } \\
\text { nuclease RuvC) (Holliday } \\
\text { junction resolvase RuvC) }\end{array}$} & \multirow{2}{*}{17740.6} & \multirow[t]{2}{*}{4.7} \\
\hline $\mathrm{NC}$ & 3254 & 36 & 4.720 & 17 & 13.5579 & & & & & \\
\hline NS & 3596 & 35 & 5.964 & 66 & 0.0245 & \multirow[t]{2}{*}{0.27} & \multirow[t]{2}{*}{ Q8YZZ2 } & \multirow[b]{2}{*}{$\begin{array}{l}\text { 2-succinyl-5-enolpyruvyl- } \\
\text { 6-hydroxy-3-cyclohexene- } \\
\text { 1-carboxylate synthase } \\
\text { (SEPHCHC synthase) } \\
\text { (EC } 2.2 .1 .9) \\
\text { (Menaquinone } \\
\text { biosynthesis protein } \\
\text { MenD) }\end{array}$} & \multirow[t]{2}{*}{65729.2} & \multirow[t]{2}{*}{5.83} \\
\hline $\mathrm{NC}$ & 3126 & 35 & 5.889 & 64 & 0.0898 & & & & & \\
\hline $\mathrm{NS}$ & 3603 & 34 & 4.470 & 64 & 0.4829 & \multirow[t]{2}{*}{1.09} & \multirow[t]{2}{*}{ Q8YM86 } & \multirow{2}{*}{$\begin{array}{l}\text { NAD }(\mathrm{P}) \mathrm{H} \text {-quinone } \\
\text { oxidoreductase chain 4-3 } \\
\text { (EC 1.6.5.-) (NAD }(\mathrm{P}) \mathrm{H} \\
\text { dehydrogenase I, subunit } \\
\text { D-3) (NDH-1, chain 4-3) }\end{array}$} & \multirow[t]{2}{*}{61013} & \multirow[t]{2}{*}{5.72} \\
\hline $\mathrm{NC}$ & 3128 & 34 & 4.564 & 62 & 0.4426 & & & & & \\
\hline $\mathrm{NS}$ & 3612 & 33 & 4.700 & 60 & 0.8317 & \multirow[t]{2}{*}{4.81} & \multirow[t]{2}{*}{ Q8Z0E5 } & \multirow[t]{2}{*}{ Penicillin-binding protein } & \multirow[t]{2}{*}{60683.9} & \multirow[t]{2}{*}{5.04} \\
\hline $\mathrm{NC}$ & 3134 & 33 & 4.700 & 60 & 0.1729 & & & & & \\
\hline NS & 3614 & 32 & 4.941 & 61 & 0.1040 & 0.69 & Q8YP23 & Peptide chain release & 61270.8 & 5.43 \\
\hline
\end{tabular}




\begin{tabular}{|c|c|c|c|c|c|c|c|c|c|c|}
\hline $\mathrm{NC}$ & 3129 & 32 & 4.856 & 62 & 0.1500 & & & factor 3 (RF-3) & & \\
\hline $\mathrm{NS}$ & 3620 & 31 & 5.200 & 59 & 0.1628 & \multirow[t]{2}{*}{1.46} & \multirow[t]{2}{*}{ Q8YQZ0 } & \multirow{2}{*}{$\begin{array}{l}\text { Urease subunit alpha (EC } \\
\text { 3.5.1.5) (Urea } \\
\text { amidohydrolase subunit } \\
\text { alpha) }\end{array}$} & \multirow[t]{2}{*}{61155.6} & \multirow[t]{2}{*}{5.23} \\
\hline $\mathrm{NC}$ & 3132 & 31 & 4.524 & 61 & 0.1116 & & & & & \\
\hline $\mathrm{NS}$ & 3623 & 30 & 4.907 & 56 & 0.7416 & \multirow{2}{*}{7.08} & \multirow[b]{2}{*}{$\begin{array}{l}\text { Q8YPL2 } \\
\\
\end{array}$} & \multirow[b]{2}{*}{$\begin{array}{l}\text { 2,3-bisphosphoglycerate- } \\
\text { independent } \\
\text { phosphoglycerate mutase } \\
\text { (BPG-independent } \\
\text { PGAM) } \\
\text { (Phosphoglyceromutase) } \\
\text { (iPGM) (EC 5.4.2.1) }\end{array}$} & \multirow[t]{2}{*}{57677.3} & \multirow[t]{2}{*}{4.99} \\
\hline $\mathrm{NC}$ & 3135 & 30 & 4.973 & 57 & 0.1047 & & & & & \\
\hline NS & 3636 & 29 & 5.867 & 53 & 0.0964 & \multirow[t]{2}{*}{0.16} & \multirow[t]{2}{*}{ Q8YM64 } & \multirow[b]{2}{*}{$\begin{array}{l}\text { Light-independent } \\
\text { protochlorophyllide } \\
\text { reductase subunit N } \\
\text { (DPOR subunit N) (LI- } \\
\text { POR subunit N) (EC } \\
1.18 .-.- \text { ) } \\
\end{array}$} & \multirow[t]{2}{*}{52534.9} & \multirow[t]{2}{*}{5.69} \\
\hline $\mathrm{NC}$ & 3141 & 29 & 5.694 & 52 & 0.5954 & & & & & \\
\hline $\mathrm{NS}$ & 3643 & 28 & 6.124 & 50 & 0.0326 & \multirow[t]{2}{*}{0.44} & \multirow[t]{2}{*}{ Q8YLT5 } & \multirow[t]{2}{*}{ Alr5211 protein } & \multirow[t]{2}{*}{52011.7} & \multirow[t]{2}{*}{8.78} \\
\hline $\mathrm{NC}$ & 3149 & 28 & 6.036 & 52 & 0.0737 & & & & & \\
\hline $\mathrm{NS}$ & 3655 & 27 & 4.890 & 45 & 0.1636 & \multirow[t]{2}{*}{0.71} & \multirow[t]{2}{*}{ Q8YPU6 } & \multirow[t]{2}{*}{ NADH dehydrogenase } & \multirow[t]{2}{*}{45675.2} & \multirow[t]{2}{*}{4.95} \\
\hline $\mathrm{NC}$ & 3163 & 27 & 4.983 & 46 & 0.2307 & & & & & \\
\hline $\mathrm{NS}$ & 3728 & 26 & 5.355 & 23 & 0.1012 & \multirow[t]{2}{*}{0.63} & \multirow[t]{2}{*}{ Q8YVB5 } & \multirow[b]{2}{*}{$\begin{array}{l}\text { Uracil } \\
\text { phosphoribosyltransferase } \\
\text { (EC 2.4.2.9) (UMP } \\
\text { pyrophosphorylase) } \\
\text { (UPRTase) } \\
\end{array}$} & 23364.1 & 5.08 \\
\hline $\mathrm{NC}$ & 3220 & 26 & 5.085 & 23 & 0.1604 & & & & & \\
\hline $\mathrm{NS}$ & 3735 & 25 & 4.444 & 21 & 1.5199 & 1.01 & P80562 & Inorganic & 18960.6 & 4.69 \\
\hline $\mathrm{NC}$ & 3228 & 25 & 4.710 & 19 & 1.5025 & & & $\begin{array}{l}\text { pyrophosphatase (EC } \\
\text { 3.6.1.1) (Pyrophosphate } \\
\text { phospho-hydrolase) } \\
\text { (PPase) }\end{array}$ & & \\
\hline NS & 3736 & 24 & 4.548 & 21 & 2.4107 & 3.94 & Q8YSE1 & Phosphoenolpyruvate & 18033.9 & 4.85 \\
\hline $\mathrm{NC}$ & 3231 & 24 & 4.944 & 18 & 0.6115 & & & synthase & & \\
\hline NS & 3738 & 23 & 4.872 & 20 & 1.1271 & 0.55 & O52749 & UPF0079 ATP-binding & 17938.7 & 4.33 \\
\hline $\mathrm{NC}$ & 3230 & 23 & 4.500 & 18 & 2.0396 & & & protein alr 2300 & & \\
\hline $\mathrm{NS}$ & 3749 & 22 & 6.048 & 19 & 0.1077 & 0.22 & Q8YNU3 & Alr4468 protein & 18081 & 6.9 \\
\hline $\mathrm{NC}$ & 3243 & 22 & 6.158 & 18 & 0.4841 & & & & & \\
\hline NS & 3752 & 21 & 5.097 & 18 & 0.2333 & 0.50 & Q8YSE1 & Phosphoenolpyruvate & 18033.9 & 4.85 \\
\hline $\mathrm{NC}$ & 3246 & 21 & 4.898 & 18 & 0.4662 & & & synthase & & \\
\hline $\mathrm{NS}$ & 3753 & 20 & 4.422 & 18 & 10.2086 & 1.96 & P80562 & Inorganic & 18960.6 & 4.69 \\
\hline $\mathrm{NC}$ & 3244 & 20 & 4.653 & 18 & 5.2084 & & & $\begin{array}{l}\text { pyrophosphatase (EC } \\
\text { 3.6.1.1) (Pyrophosphate } \\
\text { phospho-hydrolase) } \\
\text { (PPase) }\end{array}$ & & \\
\hline $\mathrm{NS}$ & 3755 & 19 & 4.100 & 18 & 0.6886 & 1.17 & O52749 & UPF0079 ATP-binding & 17938.7 & 4.33 \\
\hline $\mathrm{NC}$ & 3241 & 19 & 4.100 & 18 & 0.5871 & & & protein alr2300 & & \\
\hline NS & 3756 & 18 & 5.372 & 18 & 0.1126 & 0.17 & Q8YYZ9 & Alr0692 protein & 17425.2 & 5.37 \\
\hline $\mathrm{NC}$ & 3248 & 18 & 5.215 & 18 & 0.6489 & & & & & \\
\hline $\mathrm{NS}$ & 3757 & 17 & 6.109 & 18 & 0.3474 & 1.42 & Q8YWH5 & Molybdopterin synthase & 18097.8 & 7 \\
\hline $\mathrm{NC}$ & 3247 & 17 & 6.442 & 18 & 0.2450 & & & $\begin{array}{l}\text { catalytic subunit (EC } \\
\text { 2.8.1.12) (MPT synthase } \\
\text { subunit 2) (Molybdenum }\end{array}$ & & \\
\hline
\end{tabular}




\begin{tabular}{|c|c|c|c|c|c|c|c|c|c|c|}
\hline & & & & & & & & $\begin{array}{l}\text { cofactor biosynthesis } \\
\text { protein E) } \\
\text { (Molybdopterin- } \\
\text { converting factor large } \\
\text { subunit) (Molybdopterin- } \\
\text { converting factor subunit } \\
2 \text { ) }\end{array}$ & & \\
\hline $\mathrm{NS}$ & 3759 & 16 & 4.223 & 18 & 0.1822 & \multirow[t]{2}{*}{1.63} & \multirow[t]{2}{*}{ O52749 } & \multirow{2}{*}{$\begin{array}{l}\text { UPF0079 ATP-binding } \\
\text { protein alr2300 }\end{array}$} & \multirow[t]{2}{*}{17938.7} & \multirow[t]{2}{*}{4.3} \\
\hline $\mathrm{NC}$ & 3242 & 16 & 4.236 & 18 & 0.1118 & & & & & \\
\hline NS & 3765 & 15 & 5.252 & 17 & 7.0583 & \multirow{2}{*}{0.58} & \multirow[t]{2}{*}{ P80555 } & \multirow{2}{*}{$\begin{array}{l}\text { Allophycocyanin subunit } \\
\text { alpha } 1\end{array}$} & \multirow[t]{2}{*}{17214.5} & \multirow[t]{2}{*}{4.92} \\
\hline $\mathrm{NC}$ & 3252 & 15 & 5.085 & 17 & 12.2443 & & & & & \\
\hline $\mathrm{NS}$ & 3767 & 14 & 5.605 & 17 & 4.2938 & \multirow[t]{2}{*}{0.76} & \multirow[t]{2}{*}{ P80557 } & \multirow{2}{*}{$\begin{array}{l}\text { Allophycocyanin subunit } \\
\text { beta }\end{array}$} & \multirow[t]{2}{*}{17173.6} & \multirow[t]{2}{*}{5.46} \\
\hline $\mathrm{NC}$ & 3256 & 14 & 5.451 & 17 & 5.6380 & & & & & \\
\hline $\mathrm{NS}$ & 3771 & 13 & 4.164 & 17 & 0.3574 & \multirow[t]{2}{*}{0.55} & \multirow[t]{2}{*}{ O52749 } & \multirow{2}{*}{$\begin{array}{l}\text { UPF0079 ATP-binding } \\
\text { protein alr2300 }\end{array}$} & \multirow[t]{2}{*}{17938.7} & \multirow[t]{2}{*}{4.33} \\
\hline $\mathrm{NC}$ & 3259 & 13 & 4.225 & 17 & 0.6500 & & & & & \\
\hline $\mathrm{NS}$ & 3772 & 12 & 5.800 & 17 & 2.6184 & \multirow[t]{2}{*}{1.18} & \multirow[t]{2}{*}{ O52751 } & \multirow[b]{2}{*}{$\begin{array}{l}\text { Crossover junction } \\
\text { endodeoxyribonuclease } \\
\text { RuvC (EC 3.1.22.4) } \\
\text { (Holliday junction } \\
\text { nuclease RuvC) (Holliday } \\
\text { junction resolvase RuvC) }\end{array}$} & \multirow[t]{2}{*}{17740.6} & \multirow[t]{2}{*}{4.7} \\
\hline $\mathrm{NC}$ & 3260 & 12 & 5.800 & 17 & 2.2108 & & & & & \\
\hline $\mathrm{NS}$ & 3773 & 11 & 5.967 & 17 & 0.6276 & \multirow[t]{2}{*}{0.29} & \multirow[t]{2}{*}{ Q93SX1 } & Cytochrome b6-f complex & 17535.9 & 7.85 \\
\hline $\mathrm{NC}$ & 3257 & 11 & 6.117 & 17 & 2.1478 & & & $\begin{array}{l}\text { subunit } 4(17 \mathrm{kDa} \\
\text { polypeptide })\end{array}$ & & \\
\hline NS & 3774 & 10 & 4.059 & 17 & 1.4799 & 2.06 & O52749 & UPF0079 ATP-binding & 17938.7 & 4.33 \\
\hline $\mathrm{NC}$ & 3258 & 10 & 4.037 & 17 & 0.7195 & & & protein alr2300 & & \\
\hline $\mathrm{NS}$ & 3775 & 9 & 5.858 & 17 & 0.3655 & 0.60 & Q8YU89 & 1,4-dihydroxy-2- & 16864.4 & 5.8 \\
\hline $\mathrm{NC}$ & 3255 & 9 & 5.849 & 17 & 0.6103 & & & $\begin{array}{l}\text { naphthoyl-CoA hydrolase } \\
\text { (DHNA-CoA hydrolase) } \\
\text { (EC 3.1.2.28) (DHNA- } \\
\text { CoA thioesterase) }\end{array}$ & & \\
\hline NS & 3777 & 8 & 4.576 & 17 & 2.6173 & 1.02 & P80556 & Allophycocyanin subunit & 17680.3 & 5.06 \\
\hline $\mathrm{NC}$ & 3263 & 8 & 5.022 & 17 & 2.5633 & & & alpha-B & & \\
\hline $\mathrm{NS}$ & 3779 & 7 & 5.105 & 17 & 0.2424 & 0.80 & O52752 & Crossover junction & 17740.6 & 4.7 \\
\hline $\mathrm{NC}$ & 3261 & 7 & 4.671 & 17 & 0.3047 & & & $\begin{array}{l}\text { endodeoxyribonuclease } \\
\text { RuvC (EC 3.1.22.4) } \\
\text { (Holliday junction } \\
\text { nuclease RuvC) (Holliday } \\
\text { junction resolvase RuvC) }\end{array}$ & & \\
\hline NS & 3781 & 6 & 4.422 & 17 & 0.6460 & 0.49 & Q8YUT2 & Protein GvpK & 16947.7 & 4.65 \\
\hline $\mathrm{NC}$ & 3266 & 6 & 4.658 & 17 & 1.3085 & & & & & \\
\hline $\mathrm{NS}$ & 3783 & 5 & 5.476 & 17 & 0.1593 & 1.78 & Q8YYZ9 & Alr0692 protein & 17425.2 & 5.37 \\
\hline $\mathrm{NC}$ & 3268 & 5 & 5.296 & 17 & 0.0893 & & & & & \\
\hline NS & 3784 & 4 & 5.597 & 17 & 0.1166 & 0.62 & Q8Z017 & Small heat shock protein & 17122.6 & 5.5 \\
\hline $\mathrm{NC}$ & 3271 & 4 & 5.434 & 16 & 0.1874 & & & & & \\
\hline NS & 3793 & 3 & 5.588 & 16 & 0.3697 & 0.44 & Q8YRG9 & Alr3479 protein & 16687 & 5.26 \\
\hline $\mathrm{NC}$ & 3272 & 3 & 5.158 & 16 & 0.8422 & & & & & \\
\hline $\mathrm{NS}$ & 3794 & 2 & 4.365 & 16 & 1.1991 & 0.58 & Q8YUT1 & Gas vesicle protein GvpJ & 16597.6 & 4.73 \\
\hline $\mathrm{NC}$ & 3274 & 2 & 4.690 & 16 & 2.0607 & & & & & \\
\hline NS & 3795 & 1 & 4.821 & 16 & 0.1921 & 0.17 & Q8YUT1 & Gas vesicle protein GvpJ & 16597.6 & 4.73 \\
\hline $\mathrm{NC}$ & 3273 & 1 & 4.549 & 16 & 1.1504 & & & & & \\
\hline NS & 3805 & 0 & 4.407 & 16 & 0.3505 & 3.33 & Q8YUT1 & Gas vesicle protein GvpJ & 16597.6 & 4.73 \\
\hline
\end{tabular}




\begin{tabular}{l|l|l|l|l|l|l|l|l|l|l}
\hline $\mathrm{NC}$ & 3285 & 0 & 4.778 & 16 & 0.1053 & & & & & \\
\hline
\end{tabular}

Table 4. Showing identical protein with differential expression ( $>1.5$ Fold Regulation) in the control and sucrose treated cells. The putative gene products are also given in the table.

\begin{tabular}{|c|c|c|c|c|c|}
\hline S.N. & $\begin{array}{l}\text { Functional } \\
\text { Group }\end{array}$ & Protein Identification & Sub function & $\begin{array}{l}\text { Gene } \\
\text { Name }\end{array}$ & $\begin{array}{r}\text { Match } \\
\text { ID } \\
\end{array}$ \\
\hline 1 & Cell envelope & Penicillin-binding protein & $\begin{array}{l}\text { Murein sacculus and } \\
\text { peptidoglycan }\end{array}$ & $\operatorname{alr} 0153$ & 33 \\
\hline \multirow[t]{2}{*}{2} & \multirow[t]{2}{*}{ Energy metabolism } & $\begin{array}{l}\text { 2,3-bisphosphoglycerate-independent phosphoglycerate mutase } \\
\text { (BPG-independent PGAM) (Phosphoglyceromutase) (iPGM) } \\
\text { (EC 5.4.2.1) }\end{array}$ & Glycolysis & all4182 & 30 \\
\hline & & Phosphoenolpyruvate synthase & $\begin{array}{l}\text { Pyruvate and acetyl- } \\
\text { CoA metabolism }\end{array}$ & $\operatorname{alr} 3147$ & 24 \\
\hline \multirow[b]{2}{*}{3} & \multirow{2}{*}{$\begin{array}{l}\text { Central } \\
\text { intermediary } \\
\text { metabolism }\end{array}$} & similar to NifU protein & Nitrogen fixation & alr0692 & 5 \\
\hline & & $\begin{array}{l}\text { Inorganic pyrophosphatase (EC 3.6.1.1) (Pyrophosphate } \\
\text { phospho-hydrolase) (PPase) }\end{array}$ & $\begin{array}{l}\text { Phosphorus } \\
\text { compounds }\end{array}$ & all 3570 & 20 \\
\hline \multirow{2}{*}{4} & \multirow{2}{*}{$\begin{array}{l}\text { Unknown \& } \\
\text { Hypothetical }\end{array}$} & Gas vesicle protein GvpJ & & all2250 & 0 \\
\hline & & UPF0079 ATP-binding protein alr2300 & & alr2300 & 16,10 \\
\hline
\end{tabular}

Table 5. Spot details on commonly induced proteins under salt and sucrose treated cells of N. muscorum. $\mathrm{NS}=$ protein spots apparent on the gel of sucrose treated cells of $N$. muscorum; NN=protein spots apparent on the gel of salt treated cells of $N$. muscorum

\begin{tabular}{|c|c|c|c|c|c|c|c|c|c|c|}
\hline $\begin{array}{l}\text { File } \\
\text { Name }\end{array}$ & $\begin{array}{l}\text { Spot } \\
\text { ID }\end{array}$ & $\begin{array}{l}\text { Match } \\
\text { ID }\end{array}$ & $\begin{array}{l}\text { Apparent } \\
\text { pI }\end{array}$ & $\begin{array}{l}\text { Apparent } \\
\mathrm{MW} \\
(\mathrm{kDa}) \\
\end{array}$ & $\% \mathrm{Vol}$ & \begin{tabular}{|l|} 
Fold \\
Regulation \\
$(\mathrm{T} / \mathrm{C})$ \\
\end{tabular} & $\begin{array}{l}\text { Protein } \\
\text { Acc. No }\end{array}$ & Protein Identfication & $\begin{array}{l}\text { Theoretical } \\
\text { Mw (Da) }\end{array}$ & $\begin{array}{l}\text { Theoretical } \\
\text { pI }\end{array}$ \\
\hline $\mathrm{NN}$ & 7877 & 53 & 6.08 & 77 & 0.045 & \multirow[t]{2}{*}{1.83} & \multirow[t]{2}{*}{ Q8YZZ2 } & \multirow[b]{2}{*}{$\begin{array}{l}\text { 2-succinyl-5-enolpyruvyl- } \\
\text { 6-hydroxy-3-cyclohexene- } \\
\text { 1-carboxylate synthase } \\
\text { (SEPHCHC synthase) } \\
\text { (EC } 2.2 .1 .9) \\
\text { (Menaquinone } \\
\text { biosynthesis protein } \\
\text { MenD) }\end{array}$} & \multirow[b]{2}{*}{65729.2} & \multirow[t]{2}{*}{5.83} \\
\hline NS & 3596 & 53 & 5.96 & 66 & 0.024 & & & & & \\
\hline $\mathrm{NN}$ & 7881 & 52 & 5.32 & 76 & 0.133 & \multirow[t]{2}{*}{2.24} & \multirow[t]{2}{*}{ Q8YQU9 } & \multirow{2}{*}{$\begin{array}{l}\text { Arginine--tRNA ligase } \\
\text { (EC 6.1.1.19) (Arginyl- } \\
\text { tRNA synthetase) } \\
\text { (ArgRS) }\end{array}$} & \multirow[t]{2}{*}{65814.9} & \multirow[t]{2}{*}{5.3} \\
\hline NS & 3597 & 52 & 5.40 & 65 & 0.059 & & & & & \\
\hline $\mathrm{NN}$ & 7916 & 51 & 5.14 & 67 & 0.058 & \multirow[t]{2}{*}{0.81} & \multirow[t]{2}{*}{ Q8YXJ6 } & \multirow{2}{*}{$\begin{array}{l}\text { L-aspartate oxidase } \\
\text { (LASPO) (EC 1.4.3.16) } \\
\text { (Quinolinate synthase B) }\end{array}$} & \multirow{2}{*}{63173} & \multirow[t]{2}{*}{6.17} \\
\hline NS & 3604 & 51 & 5.27 & 64 & 0.072 & & & & & \\
\hline $\mathrm{NN}$ & 7969 & 50 & 4.70 & 60 & 0.200 & \multirow[t]{2}{*}{0.24} & \multirow[t]{2}{*}{ Q8YSY8 } & \multirow[t]{2}{*}{ All2941 protein } & \multirow[t]{2}{*}{62501} & \multirow[t]{2}{*}{9.2} \\
\hline NS & 3612 & 50 & 4.70 & 60 & 0.832 & & & & & \\
\hline $\mathrm{NN}$ & 7972 & 49 & 5.17 & 61 & 0.041 & \multirow[t]{2}{*}{0.19} & \multirow[t]{2}{*}{$\mathrm{P} 48575$} & \multirow[b]{2}{*}{$\begin{array}{l}\text { 2-isopropylmalate } \\
\text { synthase (EC 2.3.3.13) } \\
\text { (Alpha-IPM synthase) } \\
\text { (Alpha-isopropylmalate } \\
\text { synthase) }\end{array}$} & \multirow[t]{2}{*}{57761.5} & \multirow[t]{2}{*}{5.38} \\
\hline NS & 3621 & 49 & 5.29 & 58 & 0.216 & & & & & \\
\hline $\mathrm{NN}$ & 7973 & 48 & 6.48 & 61 & 0.025 & \multirow[t]{2}{*}{0.77} & \multirow[t]{2}{*}{ Q8YXT4 } & \multirow[t]{2}{*}{ NADH dehydrogenase } & \multirow[t]{2}{*}{49725.4} & \multirow[t]{2}{*}{6.13} \\
\hline NS & 3643 & 48 & 6.12 & 50 & 0.033 & & & & & \\
\hline NN & 7977 & 47 & 4.07 & 60 & 0.036 & 0.40 & & & & \\
\hline
\end{tabular}




\begin{tabular}{|c|c|c|c|c|c|c|c|c|c|c|}
\hline NS & 3610 & 47 & 4.14 & 62 & 0.089 & & & & & \\
\hline $\mathrm{NN}$ & 7978 & 46 & 4.49 & 58 & 0.591 & \multirow[t]{2}{*}{5.02} & \multirow[t]{2}{*}{ Q8YVS8 } & \multirow{2}{*}{$\begin{array}{l}60 \mathrm{kDa} \text { chaperonin } 2 \\
(\text { GroEL protein } 2) \\
(\text { Protein Cpn60 2) }\end{array}$} & \multirow[t]{2}{*}{58969.6} & \multirow[t]{2}{*}{4.93} \\
\hline NS & 3618 & 46 & 4.46 & 59 & 0.118 & & & & & \\
\hline $\mathrm{NN}$ & 7979 & 45 & 4.59 & 59 & 0.144 & \multirow[t]{2}{*}{0.28} & \multirow[t]{2}{*}{ Q8Z0C1 } & \multirow{2}{*}{$\begin{array}{l}\text { Putative diflavin } \\
\text { flavoprotein A } 5\end{array}$} & \multirow[t]{2}{*}{62572.6} & \multirow[t]{2}{*}{6.1} \\
\hline $\mathrm{NS}$ & 3611 & 45 & 4.49 & 61 & 0.508 & & & & & \\
\hline $\mathrm{NN}$ & 7984 & 44 & 5.30 & 59 & 0.157 & \multirow[t]{2}{*}{4.55} & \multirow[t]{2}{*}{ Q8YMQ0 } & \multirow[b]{2}{*}{$\begin{array}{l}\text { NAD }(\mathrm{P}) \mathrm{H} \text {-quinone } \\
\text { oxidoreductase subunit } 2 \\
(\mathrm{EC} \text { 1.6.5.-) (NAD }(\mathrm{P}) \mathrm{H} \\
\text { dehydrogenase subunit } \\
\text { 2) (NADH-plastoquinone } \\
\text { oxidoreductase subunit } \\
\text { 2) (NDH-1, subunit 2) }\end{array}$} & \multirow[b]{2}{*}{55464.6} & \multirow[t]{2}{*}{5.6} \\
\hline NS & 3627 & 44 & 5.42 & 55 & 0.034 & & & & & \\
\hline NN & 7988 & 43 & 5.09 & 58 & 0.012 & \multirow[t]{2}{*}{0.07} & \multirow[t]{2}{*}{ Q8YZR2 } & \multirow{2}{*}{$\begin{array}{l}\text { L-2,4-diaminobutyrate } \\
\text { decarboxylase }\end{array}$} & \multirow[t]{2}{*}{58500.6} & \multirow[t]{2}{*}{5.01} \\
\hline $\mathrm{NS}$ & 3620 & 43 & 5.20 & 59 & 0.163 & & & & & \\
\hline $\mathrm{NN}$ & 7994 & 42 & 4.90 & 55 & 0.435 & \multirow[t]{2}{*}{0.59} & \multirow[t]{2}{*}{ Q8YZX6 } & \multirow{2}{*}{$\begin{array}{l}\text { Anthranilate synthetase } \\
\text { alpha-subunit }\end{array}$} & \multirow[t]{2}{*}{56214.2} & \multirow[t]{2}{*}{5.16} \\
\hline NS & 3623 & 42 & 4.91 & 56 & 0.742 & & & & & \\
\hline $\mathrm{NN}$ & 8000 & 41 & 4.99 & 55 & 0.141 & \multirow[t]{2}{*}{0.52} & Q8YWF0 & UDP-N-acetylmuramoyl- & 53473.8 & 5.17 \\
\hline NS & 3634 & 41 & 5.05 & 53 & 0.270 & & & $\begin{array}{l}\text { L-alanyl-D-glutamate-- } \\
\text { 2,6-diaminopimelate } \\
\text { ligase }\end{array}$ & & \\
\hline $\mathrm{NN}$ & 8016 & 40 & 4.81 & 53 & 0.119 & 0.25 & Q8Z064 & Probable cytosol & 51918.3 & 4.87 \\
\hline NS & 3639 & 40 & 4.79 & 51 & 0.468 & & & $\begin{array}{l}\text { aminopeptidase (EC } \\
\text { 3.4.11.1) (Leucine } \\
\text { aminopeptidase) (LAP) } \\
\text { (EC 3.4.11.10) (Leucyl } \\
\text { aminopeptidase) }\end{array}$ & & \\
\hline $\mathrm{NN}$ & 8026 & 39 & 4.45 & 51 & 0.056 & 0.17 & Q8YQX9 & Trigger factor $(\mathrm{TF})$ (EC & 52381.9 & 4.43 \\
\hline NS & 3640 & 39 & 4.44 & 52 & 0.342 & & & 5.2.1.8) (PPIase) & & \\
\hline $\mathrm{NN}$ & 8035 & 38 & 4.91 & 51 & 0.043 & 0.03 & Q8YN91 & tRNA modification & 49783 & 4.9 \\
\hline NS & 3637 & 38 & 4.92 & 50 & 1.662 & & & $\begin{array}{l}\text { GTPase MnmE (EC } \\
\text { 3.6.-.-) }\end{array}$ & & \\
\hline $\mathrm{NN}$ & 8042 & 37 & 4.14 & 50 & 0.059 & 0.39 & Q8YQX9 & Trigger factor $(\mathrm{TF})(\mathrm{EC}$ & 52381.9 & 4.43 \\
\hline $\mathrm{NS}$ & 3638 & 37 & 4.20 & 52 & 0.150 & & & 5.2.1.8) (PPIase) & & \\
\hline $\mathrm{NN}$ & 8045 & 36 & 4.77 & 48 & 1.180 & 10.77 & Q8YLT0 & Alr5216 protein & 48421.9 & 4.58 \\
\hline $\mathrm{NS}$ & 3647 & 36 & 4.71 & 49 & 0.110 & & & & & \\
\hline $\mathrm{NN}$ & 8077 & 35 & 6.22 & 47 & 0.015 & 0.80 & Q8YQU4 & Precorrin-6y-dependent & 43288.1 & 6.33 \\
\hline NS & 3658 & 35 & 6.01 & 43 & 0.019 & & & methyltransferase & & \\
\hline $\mathrm{NN}$ & 8084 & 34 & 4.17 & 45 & 0.073 & 0.87 & & UNKNOWN & & \\
\hline $\mathrm{NS}$ & 3659 & 34 & 4.22 & 42 & 0.084 & & & & & \\
\hline $\mathrm{NN}$ & 8094 & 33 & 5.18 & 44 & 0.135 & 2.27 & Q8YPR1 & Phosphoglycerate kinase & 42441.5 & 5.15 \\
\hline NS & 3663 & 33 & 5.29 & 41 & 0.059 & & & (EC 2.7.2.3) & & \\
\hline $\mathrm{NN}$ & 8126 & 32 & 4.93 & 41 & 0.109 & 0.24 & P58571 & Magnesium-chelatase & 41245.2 & 5.03 \\
\hline $\mathrm{NS}$ & 3666 & 32 & 4.94 & 40 & 0.454 & & & $\begin{array}{l}\text { subunit ChlI (EC } \\
6.6 .1 .1)(\mathrm{Mg}- \\
\text { protoporphyrin IX } \\
\text { chelatase) } \\
\end{array}$ & & \\
\hline $\mathrm{NN}$ & 8127 & 31 & 5.07 & 41 & 0.023 & 0.39 & P70801 & Glucanase & 37896.1 & 5.13 \\
\hline $\mathrm{NS}$ & 3672 & 31 & 5.05 & 38 & 0.060 & & & & & \\
\hline $\mathrm{NN}$ & 8135 & 30 & 5.68 & 39 & 0.021 & 0.21 & Q8YQG6 & Cyclic pyranopterin & 36878.3 & 6.25 \\
\hline NS & 3679 & 30 & 5.70 & 36 & 0.098 & & & $\begin{array}{l}\text { monophosphate synthase } \\
\text { (EC 4.1.99.18) }\end{array}$ & & \\
\hline
\end{tabular}




\begin{tabular}{|c|c|c|c|c|c|c|c|c|c|c|}
\hline & & & & & & & & $\begin{array}{l}\text { (Molybdenum cofactor } \\
\text { biosynthesis protein A) }\end{array}$ & & \\
\hline $\mathrm{NN}$ & 8139 & 29 & 5.31 & 39 & 0.048 & \multirow[t]{2}{*}{0.18} & \multirow[t]{2}{*}{ Q8YUM5 } & \multirow[b]{2}{*}{$\begin{array}{l}\text { Ketol-acid } \\
\text { reductoisomerase (EC } \\
\text { 1.1.1.86) (Acetohydroxy- } \\
\text { acid isomeroreductase) } \\
\text { (Alpha-keto-beta- } \\
\text { hydroxylacyl } \\
\text { reductoisomerase) }\end{array}$} & \multirow[t]{2}{*}{36010.9} & \multirow[t]{2}{*}{5.4} \\
\hline NS & 3680 & 29 & 5.36 & 36 & 0.273 & & & & & \\
\hline $\mathrm{NN}$ & 8149 & 28 & 6.58 & 38 & 0.086 & \multirow[t]{2}{*}{1.64} & \multirow[t]{2}{*}{ Q8YUS1 } & \multirow{2}{*}{$\begin{array}{l}\text { Protease HtpX homolog } \\
(\text { EC 3.4.24.-) }\end{array}$} & \multirow{2}{*}{30638.5} & \multirow[t]{2}{*}{9} \\
\hline NS & 3699 & 28 & 6.17 & 30 & 0.052 & & & & & \\
\hline $\mathrm{NN}$ & 8189 & 27 & 6.11 & 33 & 0.020 & \multirow[t]{2}{*}{0.44} & \multirow[t]{2}{*}{ Q8YS90 } & \multirow{2}{*}{$\begin{array}{l}\text { Mg-protoporphyrin IX } \\
\text { methyl transferase }\end{array}$} & \multirow[t]{2}{*}{25344.8} & \multirow[t]{2}{*}{6.23} \\
\hline NS & 3712 & 27 & 6.02 & 25 & 0.045 & & & & & \\
\hline $\mathrm{NN}$ & 8208 & 26 & 5.67 & 30 & 0.071 & \multirow{2}{*}{0.70} & \multirow[t]{2}{*}{ Q8YT99 } & \multirow{2}{*}{$\begin{array}{l}\text { Glucose-1-P } \\
\text { cytidylyltransferase } \\
\end{array}$} & \multirow[t]{2}{*}{29391.6} & \multirow[t]{2}{*}{5.69} \\
\hline $\mathrm{NS}$ & 3704 & 26 & 5.69 & 28 & 0.101 & & & & & \\
\hline $\mathrm{NN}$ & 8232 & 25 & 4.33 & 28 & 0.061 & \multirow{2}{*}{0.40} & \multirow[t]{2}{*}{ Q8YLN8 } & \multirow{2}{*}{$\begin{array}{l}\text { Riboflavin synthase } \\
\text { alpha chain }\end{array}$} & \multirow[t]{2}{*}{23518.8} & \multirow[t]{2}{*}{4.75} \\
\hline NS & 3719 & 25 & 4.32 & 23 & 0.153 & & & & & \\
\hline $\mathrm{NN}$ & 8310 & 24 & 4.75 & 19 & 0.244 & \multirow[t]{2}{*}{0.10} & Q8YUQ7 & Alr2278 protein & 21191.7 & 4.63 \\
\hline $\mathrm{NS}$ & 3736 & 24 & 4.55 & 21 & 2.411 & & & & & \\
\hline $\mathrm{NN}$ & 8313 & 23 & 4.10 & 18 & 0.637 & 0.92 & P07120 & C-phycocyanin subunit & 18255.6 & 5 \\
\hline $\mathrm{NS}$ & 3755 & 23 & 4.10 & 18 & 0.689 & & & beta & & \\
\hline $\mathrm{NN}$ & 8314 & 22 & 5.02 & 19 & 0.040 & 0.04 & Q8YNA6 & Glutathione S- & 20774.1 & 4.89 \\
\hline $\mathrm{NS}$ & 3738 & 22 & 4.87 & 20 & 1.127 & & & transferase & & \\
\hline $\mathrm{NN}$ & 8329 & 21 & 5.86 & 18 & 0.060 & 0.40 & Q8YNU3 & Alr4468 protein & 18081 & 6.9 \\
\hline NS & 3763 & 21 & 5.87 & 17 & 0.149 & & & & & \\
\hline $\mathrm{NN}$ & 8330 & 20 & 4.37 & 18 & 0.052 & 0.24 & Q06881 & Biotin carboxyl carrier & 19048.7 & 4.63 \\
\hline NS & 3750 & 20 & 4.29 & 18 & 0.212 & & & $\begin{array}{l}\text { protein of acetyl-CoA } \\
\text { carboxylase (BCCP) } \\
\end{array}$ & & \\
\hline $\mathrm{NN}$ & 8332 & 19 & 6.49 & 18 & 0.036 & 0.34 & Q8YME4 & Methylated-DNA-- & 19730.8 & 7.72 \\
\hline NS & 3749 & 19 & 6.05 & 19 & 0.108 & & & $\begin{array}{l}\text { protein-cysteine } \\
\text { methyltransferase (EC } \\
\text { 2.1.1.63) (6-O- } \\
\text { methylguanine-DNA } \\
\text { methyltransferase) (O-6- } \\
\text { methylguanine-DNA- } \\
\text { alkyltransferase) } \\
\end{array}$ & & \\
\hline $\mathrm{NN}$ & 8341 & 18 & 4.56 & 18 & 1.556 & 0.15 & P80562 & Inorganic & 18960.6 & 4.69 \\
\hline NS & 3753 & 18 & 4.42 & 18 & 10.209 & & & $\begin{array}{l}\text { pyrophosphatase (EC } \\
\text { 3.6.1.1) (Pyrophosphate } \\
\text { phospho-hydrolase) } \\
\text { (PPase) }\end{array}$ & & \\
\hline $\mathrm{NN}$ & 8342 & 17 & 5.13 & 18 & 2.346 & 10.06 & P07120 & C-phycocyanin subunit & 18255.6 & 5 \\
\hline NS & 3752 & 17 & 5.10 & 18 & 0.233 & & & beta & & \\
\hline $\mathrm{NN}$ & 8345 & 16 & 6.74 & 18 & 0.028 & 0.08 & Q8YNU3 & Alr4468 protein & 18081 & 6.9 \\
\hline $\mathrm{NS}$ & 3757 & 16 & 6.11 & 18 & 0.347 & & & & & \\
\hline $\mathrm{NN}$ & 8350 & 15 & 5.32 & 17 & 0.325 & 2.89 & Q8YPF9 & Arginine biosynthesis & 18553.3 & 5.39 \\
\hline NS & 3756 & 15 & 5.37 & 18 & 0.113 & & & $\begin{array}{l}\text { bifunctional protein } \\
\text { ArgJ }\end{array}$ & & \\
\hline $\mathrm{NN}$ & 8352 & 14 & 4.33 & 17 & 0.063 & 0.35 & O52749 & UPF0079 ATP-binding & 17938.7 & 4.33 \\
\hline $\mathrm{NS}$ & 3759 & 14 & 4.22 & 18 & 0.182 & & & protein alr2300 & & \\
\hline $\mathrm{NN}$ & 8356 & 13 & 5.26 & 17 & 5.988 & 0.85 & Q8YYZ9 & Alr0692 protein & 17425.2 & 5.37 \\
\hline NS & 3765 & 13 & 5.25 & 17 & 7.058 & & & & & \\
\hline
\end{tabular}




\begin{tabular}{|c|c|c|c|c|c|c|c|c|c|c|}
\hline $\mathrm{NN}$ & 8360 & 12 & 5.80 & 17 & 3.385 & \multirow[t]{2}{*}{1.29} & \multirow[t]{2}{*}{ P35796 } & \multirow{2}{*}{$\begin{array}{l}\text { Phycoerythrocyanin } \\
\text { alpha chain }\end{array}$} & \multirow[t]{2}{*}{17454.5} & \multirow[t]{2}{*}{6.27} \\
\hline $\mathrm{NS}$ & 3772 & 12 & 5.80 & 17 & 2.618 & & & & & \\
\hline NN & 8363 & 11 & 5.94 & 17 & 0.422 & \multirow[t]{2}{*}{1.16} & \multirow[t]{2}{*}{ Q93SX1 } & \multirow{2}{*}{$\begin{array}{l}\text { Cytochrome b6-f } \\
\text { complex subunit } 4 \text { (17 } \\
\text { kDa polypeptide) }\end{array}$} & \multirow[t]{2}{*}{17535.9} & \multirow[t]{2}{*}{7.85} \\
\hline NS & 3775 & 11 & 5.86 & 17 & 0.365 & & & & & \\
\hline $\mathrm{NN}$ & 8373 & 10 & 4.20 & 17 & 0.328 & \multirow[t]{2}{*}{0.92} & & & & \\
\hline $\mathrm{NS}$ & 3771 & 10 & 4.16 & 17 & 0.357 & & & & & \\
\hline $\mathrm{NN}$ & 8380 & 9 & 4.08 & 17 & 0.094 & \multirow[t]{2}{*}{0.11} & \multirow[t]{2}{*}{ O52749 } & \multirow{2}{*}{$\begin{array}{l}\text { UPF0079 ATP-binding } \\
\text { protein alr } 2300\end{array}$} & \multirow[t]{2}{*}{17938.7} & \multirow[t]{2}{*}{4.33} \\
\hline NS & 3768 & 9 & 4.26 & 17 & 0.882 & & & & & \\
\hline $\mathrm{NN}$ & 8393 & 8 & 6.39 & 17 & 0.010 & \multirow[t]{2}{*}{0.02} & \multirow[t]{2}{*}{ Q93SX1 } & \multirow{2}{*}{$\begin{array}{l}\text { Cytochrome b6-f } \\
\text { complex subunit } 4 \text { (17 } \\
\text { kDa polypeptide) }\end{array}$} & \multirow[t]{2}{*}{17535.9} & \multirow[t]{2}{*}{7.85} \\
\hline NS & 3773 & 8 & 5.97 & 17 & 0.628 & & & & & \\
\hline NN & 8396 & 7 & 4.49 & 17 & 0.118 & \multirow[t]{2}{*}{0.01} & \multirow[t]{2}{*}{ Q8YUT2 } & \multirow[t]{2}{*}{ Protein GvpK } & \multirow[t]{2}{*}{16947.7} & \multirow[t]{2}{*}{4.65} \\
\hline $\mathrm{NS}$ & 3770 & 7 & 4.41 & 17 & 9.673 & & & & & \\
\hline $\mathrm{NN}$ & 8399 & 6 & 4.08 & 17 & 0.014 & \multirow[t]{2}{*}{0.07} & \multirow[t]{2}{*}{ O52749 } & \multirow{2}{*}{$\begin{array}{l}\text { UPF0079 ATP-binding } \\
\text { protein alr2300 }\end{array}$} & \multirow[t]{2}{*}{17938.7} & \multirow[t]{2}{*}{4.33} \\
\hline $\mathrm{NS}$ & 3780 & 6 & 4.27 & 17 & 0.206 & & & & & \\
\hline $\mathrm{NN}$ & 8403 & 5 & 5.50 & 17 & 0.185 & 0.04 & Q8YQF0 & 2-C-methyl-D-erythritol & 17873.6 & 5.56 \\
\hline NS & 3767 & 5 & 5.61 & 17 & 4.294 & & & $\begin{array}{l}\text { 2,4-cyclodiphosphate } \\
\text { synthase (MECDP- } \\
\text { synthase) (MECPP- } \\
\text { synthase) (MECPS) (EC } \\
\text { 4.6.1.12) } \\
\end{array}$ & & \\
\hline $\mathrm{NN}$ & 8410 & 4 & 4.38 & 17 & 0.078 & 0.12 & O52749 & UPF0079 ATP-binding & 17938.7 & 4.33 \\
\hline NS & 3781 & 4 & 4.42 & 17 & 0.646 & & & protein alr2300 & & \\
\hline $\mathrm{NN}$ & 8432 & 3 & 5.84 & 16 & 1.545 & 9.55 & Q8YU89 & 1,4-dihydroxy-2- & 16864.4 & 5.8 \\
\hline NS & 3785 & 3 & 5.81 & 17 & 0.162 & & & $\begin{array}{l}\text { naphthoyl-CoA } \\
\text { hydrolase (DHNA-CoA } \\
\text { hydrolase) (EC 3.1.2.28) } \\
\text { (DHNA-CoA } \\
\text { thioesterase) }\end{array}$ & & \\
\hline $\mathrm{NN}$ & 8438 & 2 & 6.73 & 16 & 0.151 & 1.25 & Q8Z033 & Diacylglycerol kinase & 16338.5 & 6.81 \\
\hline $\mathrm{NS}$ & 3801 & 2 & 6.14 & 16 & 0.120 & & & & & \\
\hline NN & 8449 & 1 & 5.85 & 16 & 0.150 & 0.30 & Q8YYW0 & Urease accessory protein & 16559.1 & 5.86 \\
\hline $\mathrm{NS}$ & 3791 & 1 & 5.82 & 16 & 0.501 & & & UreE & & \\
\hline $\mathrm{NN}$ & 8450 & 0 & 4.29 & 16 & 0.061 & 0.22 & Q8YUT2 & Gas vesicle protein GvpJ & 16597.6 & 4.73 \\
\hline NS & 3788 & 0 & 4.40 & 16 & 0.276 & & & & & \\
\hline
\end{tabular}

Table 6. Showing identical protein with differential expression ( $>1.5$ Fold Regulation) in the salt treated and sucrose treated cells. The putative gene products are also given in the table.

\begin{tabular}{|c|c|c|c|c|c|}
\hline S.N. & Functional Group & Protein Identification & Sub function & ORF'S & $\begin{array}{c}\text { Match } \\
\text { ID }\end{array}$ \\
\hline 1 & $\begin{array}{l}\text { Amino acid } \\
\text { biosynthesis }\end{array}$ & $\begin{array}{l}\text { Arginine biosynthesis bifunctional protein ArgJ } 2 \text { [Cleaved into: } \\
\text { Arginine biosynthesis bifunctional protein ArgJ alpha chain; } \\
\text { Arginine biosynthesis bifunctional protein ArgJ beta chain] } \\
\text { [Includes: Glutamate N-acetyltransferase (EC 2.3.1.35) (Ornithine } \\
\text { acetyltransferase) (OATase) (Ornithine transacetylase); Amino- } \\
\text { acid acetyltransferase (EC 2.3.1.1) (N-acetylglutamate synthase) } \\
\text { (AGSase)] }\end{array}$ & $\begin{array}{l}\text { Glutamate family } \\
\text { / Nitrogen } \\
\text { assimilation }\end{array}$ & alr4235 & 15 \\
\hline 2 & $\begin{array}{l}\text { Biosynthesis of } \\
\text { cofactors, prosthetic } \\
\text { groups, and carriers }\end{array}$ & $\begin{array}{l}\text { 2-succinyl-5-enolpyruvyl-6-hydroxy-3-cyclohexene-1-carboxylate } \\
\text { synthase (SEPHCHC synthase) (EC 2.2.1.9) (Menaquinone } \\
\text { biosynthesis protein MenD) }\end{array}$ & $\begin{array}{l}\text { Menaquinone and } \\
\text { ubiquinone }\end{array}$ & alr0312 & 53 \\
\hline
\end{tabular}




\begin{tabular}{|c|c|c|c|c|c|}
\hline \multirow{3}{*}{3} & \multirow{3}{*}{ Cellular processes } & probable hemolysin & Cell killing & alr5216 & 36 \\
\hline & & Protease HtpX homolog (EC 3.4.24.-)heat shock protein X & Chaperones & all2263 & 28 \\
\hline & & $60 \mathrm{kDa}$ chaperonin 2 (GroEL protein 2) (Protein Cpn60 2) & Chaperones & alr1896 & 46 \\
\hline 4 & $\begin{array}{l}\text { Photosynthesis and } \\
\text { respiration }\end{array}$ & $\begin{array}{l}\text { NAD }(\mathrm{P}) \mathrm{H} \text {-quinone oxidoreductase subunit } 2 \text { (EC 1.6.5.-) } \\
\text { (NAD }(\mathrm{P}) \mathrm{H} \text { dehydrogenase subunit 2) (NADH-plastoquinone } \\
\text { oxidoreductase subunit 2) (NDH-1, subunit 2) }\end{array}$ & $\begin{array}{l}\text { NADH } \\
\text { dehydrogenase }\end{array}$ & all4883 & 44 \\
\hline \multirow{4}{*}{5} & \multirow{4}{*}{$\begin{array}{l}\text { Unknown \& } \\
\text { Hypothetical }\end{array}$} & $\begin{array}{l}\text { Arginine--tRNA ligase (EC 6.1.1.19) (Arginyl-tRNA synthetase) } \\
\text { (ArgRS) }\end{array}$ & & all3717 & 52 \\
\hline & & C-phycocyanin subunit beta & & alr0528 & 17 \\
\hline & & Phosphoglycerate kinase (EC 2.7.2.3) & & all4131 & 33 \\
\hline & & $\begin{array}{l}\text { 1,4-dihydroxy-2-naphthoyl-CoA hydrolase (DHNA-CoA hydrolase) } \\
\text { (EC 3.1.2.28) (DHNA-CoA thioesterase) }\end{array}$ & & alr2465 & 3 \\
\hline
\end{tabular}

